\title{
HASTANELERDE ÖZEL HASTALAR İÇIN BULANIK HEDEF PROGRAMLAMA İLE MENÜ PLANLAMASI
}

\section{Safiye Özlem KAÇMAZ (ozlemkacmazz@hotmail.com)}

Kırıkkale Üniversitesi, Mühendislik Fakültesi, Endüstri Mühendisliği Bölümü

Nesrin ŞENGÜL (nsrn_sngl@hotmail.com)

Kırıkkale Üniversitesi, Mühendislik Fakültesi, Endüstri Mühendisliği Bölümü

Tamer EREN (teren@kku.edu.tr)

Kırıkkale Üniversitesi, Mühendislik Fakültesi, Endüstri Mühendisliği Bölümü

\section{ÖZET}

Toplu beslenme alanlarında yiyecek ve içeceklerin gerekli enerji ve besin ögelerini karşılayacak şekilde planlanması gerekmektedir. Menü planlamada besin ögelerinin çeşitliliği, hedeflerin birden fazla olması ve yiyecekler arasinda uyum aranması planlama sürecini karmaşık hale getirmektedir. Bu çalışmada hastanelerde personel, diyabet, mide ve karaciğer hastaları için bir aylık menü planı oluşturulmuştur. Verilerin kesin değer aralıkları ile belirtilememesi nedeni ile Bulanık Hedef Programlama kullanılmıştır. $\mathrm{Bu}$ nedenle kişilerin alması gereken günlük besin değerleri \%5 bulanıklaştırılmıştır. Oluşturulan matematiksel model ILOG 12.6.2 sürümü ile çözülmüştür. Çözüm sonucu oluşturulan menüler zamandan tasarruf edilmesini sağlayarak sistematik bir yapı ortaya çıkarmıştır.

Anahtar Kelimeler: Bulanık hedef programlama, Menü planlama, Hastane, Besin öğeleri 


\section{MENU PLANNING WITH FUZZY GOAL PROGRAMMING FOR SPECIAL PATIENTS IN HOSPITALS}

Safiye Özlem KAÇMAZ (ozlemkacmazz@hotmail.com)

Kırlkkale University, Faculty of Engineering, Industrial Engineering Department Nesrin ŞENGÜL (nsrn_sngl@hotmail.com)

Kırlkkale University, Faculty of Engineering, Industrial Engineering Department Tamer EREN (teren@kku.edu.tr)

Kırlkkale University, Faculty of Engineering, Industrial Engineering Department

\section{ABSTRACT}

In the public food areas, food and beverages need to be planned to meet the energy and nutrition requirements. The diversity of the foods, having multiple targets and looking for harmony between the foods muck the planning process up for menu planning. In this study, meal plan for a whole month is created for hospital staffs and patients who have diabetes, stomach and liver diseases. Fuzzy goal programming has been applied for the reason that the data can not be defined with the range of absolute value and the daily nutritional value that people should take has been blurred by $5 \%$. The mathematical model which is developed is solved with ILOG 12.6.2 version. The menus which are created as a result of the solution provide saving on time and find out a systematic structure.

Keywords: Fuzzy goal programming, Menu planning, Hospital, Food items 


\section{GİRIŞ̧}

Bir ülkenin gelişmişliği insanların sağlıklı ve zihinsel yönden güçlü olmasına gereksinim vardır. Bu gereksinim dengeli ve sağlıklı beslenerek mümkün olmaktadır. Bunun için toplu beslenme sistemlerinde gerekli enerji ve besin ögelerini karşılayacak şekilde bir menü planlaması oluşturulur.

İnsanların büyüme ve gelişmesinin sağlıklı olabilmesi için beslenme önemli bir faktördür. Menü planlama yiyecek ve içeceklerin bir arada uyumlu bir şekilde sunulmasıdır. Toplu beslenme alanlarında bu planın önemi çok daha fazladır. Menü planlaması zaman, emek ve bilgi işidir. Menü planı yapılmadan önce doğru bir menü analizi yapılması gerekmektedir. Dengeli beslenmenin sağlanabilmesi için her besin öğesinden belirli miktarda vücuda alınmalıdır. Menüyü planlayan kişilerin yiyeceklerin temel özellikleri ve uyumu hakkında bilgi sahibi olmaları oldukça önemlidir.

Hedef Programlama, çok sayıda hedef veya amaçların bulunduğu doğrusal programlama problemlerine uygulanan bir yöntemdir. Doğrudan amaçları optimize eden doğrusal programlamanın aksine, hedef programlama, hedef değerler ve gerçekleşmiş sonuçlar arasındaki sapmaları minimize ederek, çatışan amaçları yönetmek amaciyla kullanılır (Leung vd., 2001). Bulanık hedef programlama ise belirsiz parametreler, kesin olmayan değerler için uygulanan bir yöntemdir. Hedef programlamanın işgücü planlamas1, üretim planlaması, ulaştırma ve lojistik, sağlık hedeflerinin planlanması, kuruluş yeri seçimi, pazarlama stratejilerinin planlaması gibi birçok uygulama alanı bulunmaktadır.

$\mathrm{Bu}$ çalışmada bulanık hedef programlama kullanılarak sağlık alanında bir uygulama yapılmıştır. Uygulamada hastanede öğle yemeği için dengeli bir dağıtım sağlanmaya çalışılmıştır. Menüler personeller, diyabet, mide ve karaciğer hastalığı olan kişiler için oluşturulmuştur. Belirlenen menülerde kişilerin günlük besin ögesi ihtiyaçlarının karşılanmasına dikkat edilmiştir.

Yapılan çalışma planı şu şekildedir: Çalışmanın ilk bölümünde giriş, ikinci bölümünde menü planlamasının önemi ve ele alınan hastalıklarda beslenmenin öneminden bahsedilmiştir. Üçüncü 
bölümde bulanık hedef programlama tekniği ile ilgili bilgi verilmiştir. Dördüncü bölümde literatür taraması yapılmış ve beşinci bölümde uygulama kısmı olan menü planlaması problemi ele alınmıştır. Son bölüm olan altıncı bölümde ise sonuçlar değerlendirilmiştir.

\section{MENÜ PLANLAMASI VE ÖNEMİ}

Beslenme; insanın büyüme, gelişme ve sağlıklı olabilmesi için gereken enerji ve besin öğelerinin vücuda alınmasıdır. Sağlığı korumak ve geliştirmek için vücudun gereksinimi olan tüm besin öğelerinin yeterli miktarda alınarak kullanabilmesi gereklidir. $\mathrm{Bu}$ nedenle beslenme doğru zamanlarda bilinçli yapılması gereken bir eylemdir. Beslenmenin, alınması gereken enerji ve besin ögelerini karşılayacak şekilde olmasını sağlayacak plan menü planlamadır.

Menü planlamanın çoğunlukla kullanıldığı yerler kalabalık olarak nitelendirebileceğimiz okul, işyeri, hastane vb. alanlardır. Bu gibi alanlar 'toplu beslenme sistemleri' olarak adlandirılmaktadir. Menü, kisaca toplu beslenme sistemlerinde servis edilen yemeklerin listesi olarak tanımlanabilir. Toplu beslenme sistemlerinin başarısı yiyeceklerin seçimine ve servisine, dolayısıyla menüye ve menü planlamasına bağlıdır. Menü planlamasını önemli kılan sebepler yiyecek seçimlerinin rastgele değil belirli etmenler dahilinde belirlenmesidir.

Menü planlaması karmaşık bir süreçtir. Menülere çeşitli şekilde sınıflama yapılabilir. Ancak genellikle çalışan personele hizmet veren toplu beslenme sistemlerinde "set-seçimsiz menüler" kullanılır. Seçimsiz menüler set şeklindedir ve yemek seçim şansı tanımamaktadır. Bu menülerde yer alan yemek sayısı 3-4 kapla sinırlandırılır (Beyhan ve Ciğerim, 1995).

Yapılan çalışmada hastane personelleri için menü planı oluşturulmuştur. Oluşturulan menü planı 3 hastalık için özelleştirilmiştir. $\mathrm{Bu}$ hastalıklar: diyabet, mide ve karaciğer hastalıklarıdır. Ele alınan hastalıkların seçilme nedeni ise çok özel durumların olmadığı varsayımı ve günlük almaları gereken besin miktarlarının sağlıklı bireylerle hemen hemen aynı olmasına rağmen yiyecekleri yemeklerin farklılık göstermesidir. 


\subsection{Diyabet Hastalığında Beslenme}

Pankreasın ürettiği insülinin yetersiz veya etkisiz kaldığ 1 durumlarda diyabet ortaya çıkmaktadır. Diyabet hastaları için doğru ve düzenli beslenme oldukça önemlidir. Beslenmelerine dikkat etmelerindeki ana amaç kan şekerini uygun seviyede tutmaktır. Yiyeceklerde en fazla bulunan besin ögesi karbonhidratlardır. Basit ve kompleks olmak üzere ikiye ayrılır. Basit karbonhidratlar komplekslere göre kan şekerini daha hızlı artırırlar. Bu nedenle reçel, bal, tatlılar ve şekerli yiyecekler tercih edilmemelidir. İhtiyacımızı karşılayacağımız karbonhidrat kaynakları ise kepekli ve tam tahıllı ürün ve unlu mamuller, kuru baklagiller, sebzeler ve meyveler olmalıdır. Karbonhidratlı yiyeceklerin sindirim sisteminde parçalanmayan kısımlarına posa denir. Posalar da suda çözünebilen ve çözünemeyen olmak üzere ikiye ayrilır. Hastalar sebzeler, yulaf, kuru baklagiller ve meyvelerde bulunan suda çözünebilenleri yemelidir. Kepekli mamuller, tam buğday unu, bulgur, rafine edilmemiş pirinç ise suda çözünemeyen posalara ait yiyeceklerdir. Bezelye, kuru fasulye, barbunya, nohut, mercimek ve yulaf gibi yiyecekler kan şekerinin daha yavaş yükselmesini sağladıkları için tüketilmesi yararlıdır. $\mathrm{Bu}$ yiyecekler aynı zamanda kabızlığın ve bazı bağırsak hastalıklarının önlenmesinde de etkilidir. Günlük alınması gereken posa miktarı 20-35 gr arasında değişmektedir. Bunlar dışında beyaz ekmek yerine kepekli ekmek, pirinç yerine bulgur, meyve suyu yerine meyve tüketilmeli ve ögünlerde salata bulundurmaya dikkat edilmelidir (Ersin Bayrak, 2014).

\subsection{Karaciğer Hastalığında Beslenme}

Karaciğer hastalarının beslenmelerinde, doğru yiyecekleri bulmaları çok önemlidir. Beslenme programında antioksidan içeren besinlerin arttırılması tedaviye katkı sağlayacaktır. Karaciğer hastalarının bol bol brokoli, brüksel lahanası gibi yiyecekleri haşlayarak yemesinde fayda vardır. Karaciğere en çok zarar veren etmen alkoldür. Alkolden uzak durulmalıdır. Hayvansal yă̆ içeriği ve kolesterol içeriği yüksek besinlerin tüketiminden kaçınılmalıdır. Şarküteri ürünleri sosis, salam, sucuk tüketilmemelidir. Günlük 
taze meyve ve sebze tüketimi arttırılmalıdır. Karbonhidrat ve şeker oranı aşırı yüksek olan beslenme programından uzak durulmalıdır. Doğal ürünler tercih edilmeli ve paketli hazır gidalardan kaçınılmalıdır (https://www.medikalakademi.com.tr/karacigeryaglanmasi-ve-beslenme-koruyucu-ve-zararli-besinler/). Karaciğer hastalarının yediklerine dikkat etmesi kadar diğer bir önemli husus ne kadar tüketmeleri gerektiğidir. Yenilen porsiyonlara çok dikkat edilmesi gerekir.

\subsection{Mide Rahatsızlıklarında Beslenme}

Mide hastalıkları çok geniş bir alan olmasına ve çeşitleri bulunmasına rağmen yaptığımız çalışmada mide ülseri, gastrit ve reflü üzerinde durulmuştur. $\mathrm{Bu}$ hastalıkların beslenmeleri için diyetler incelendiğinde ise çok özel durumlar hariç serbest ve yasak gıdaların benzerlik gösterdiği varsayılarak bir grup altında toplanabileceği görülmüştür.

Mide hastaları; yağda kavrulmadan hazırlanmış, et suyu katılmamış, kremasız ve az yağlı çorbaları tüketebilmektedir. Turşu, soğan, sarımsak, limon tuzu, zeytin, sirke, acılı ve bol salçalı besinlerden kaçınmalıdır. Ağrıya neden olmadığı sürece tüm sebze ve meyveleri yiyebilmektedir. Yağda kızarmış ve kavrulmuş etler, sucuk, pastırma, salam, sosis, salamura balık gibi besinlerden uzak durmalıdır. Haşlanmış, ızgara veya fırında pişirilmiş kırmızı ya da beyaz et yiyebilmektedir. Kurubaklagil (kurufasulye, nohut, barbunya, mercimek) yemeklerinin tüketim sıklığını oldukça azaltmalıdır. Kremalı, çikolatalı, kızarmış tatlılar ve soslu besinlerden uzak durmalıdır. Beyaz ekmek, sade makarna, pirinç, mısır, irmik, erişte, şehriye tüketebilmektedir. Mayalı yapılmış hamur işi besinlerden; ağır şerbetli ve yağlı tatlılardan kaçınmalıdır. Şekerli besinlerden, sütlü tatlılar ve meyveli tatlıları tercih etmelidir(http://www.milliyet.com.tr/mide-sorunu-olanlarnasil-pembenar-detay-genelsaglik-2241909/).

\section{BULANIK HEDEF PROGRAMLAMA}

Çok seçenekli karar verme problemlerinde kullanılan en yaygın yöntemlerden biri bulanık hedef programlamadır. Bu yöntem hedef 
değerlerin karar verici tarafindan kesin olarak belirlenememesi durumunda ele alınır ve hedefler bulanıklaştırılır. Hedef değerlerin bulanık düzeylerinin belirlenmesinde bulanık küme teorisinden faydalanılır (Zimmerman, 1978; Narasimhan, 1980). Bulanık Küme Teorisi'nin kullanılması karar vericiye hedef değerlerin belirlenmesindeki zorlukta avantaj sağlamakta ve bu hedef değerler daha sonra doğal dil kurallarıyla sayısallaştırılabilmektedir. Hedef Programlamada net olarak ifade edilen değerler bulanık hedef programlama ile esneklik kazanmaktadır (Kağnıcıŏlu,2006). Parametrelerinin hepsi bulanık olan öncelikli bir model aşağıdaki gibi ifade edilebilir.

Çalışmada eşitlik (1)'de hedeflenen besin değerlerinden sapmaları minimize etmek amaçlanmıştır. Eşitlik (2) ile kişinin günlük alması gereken besin değerleri ifade edilmiştir. Eşitlik (3) yemeklerle ilgili oluşturulan kısıtlarda kullanılmış, eşitlik (5) modeldeki negatif olmama kısıtlarını ifade etmiştir. Çalışmada öncelikli bir durum olmadığı için eşitlik (4) kullanılmamıştır.

\section{$\underline{\text { Amaç Fonksiyonu }}$}

$$
\mathrm{Z}_{\min }=\sum_{k=1}^{l} \sum_{i=1}^{m} \mathrm{P}_{\mathrm{k}}\left(\mathrm{d}_{\mathrm{i}}+\mathrm{d}_{\mathrm{i}}\right)
$$

$\underline{\text { Kisitlar }}$

$$
\begin{gathered}
\sum_{j=1}^{n}\left(\tilde{\mathrm{a}}_{i j} x_{j}\right)-\mathrm{d}_{\mathrm{i}}+\mathrm{d}_{\mathrm{i}}=\mathrm{b}_{\mathrm{i} . . .} \mathrm{i}=1,2, ., \mathrm{m} \text { (Hedefler) } \\
\left.\sum_{j=1}^{n}\left(\tilde{\mathrm{a}}_{t j} x_{j}\right)(\leq, \geq,=) \mathrm{b}_{\mathrm{t} . . .} \mathrm{t}=1,2, \ldots, \mathrm{v} \ldots \text { (Model Kisitlar }\right) \\
\mathrm{P} 1>\mathrm{P} 2 \ldots>\mathrm{Pk} \quad \mathrm{k}=1,2, . ., \mathrm{l} \\
\mathrm{Xj}, \mathrm{d}_{\mathrm{i}}^{+}, \mathrm{d}_{\mathrm{i}}{ }^{-} \geq 0 \quad \mathrm{i}=1,2, \ldots, \mathrm{j}=1,2, \ldots, \mathrm{n}
\end{gathered}
$$

Burada,

$\mathrm{P}_{\mathrm{k}}: \mathrm{k}$. hedefin öncelik sıras1

$\mathrm{d}_{\mathrm{i}}^{+}: \mathrm{i}$. hedeften pozitif sapma miktarı

$\mathrm{d}_{\mathrm{i}}{ }^{-}: \mathrm{i}$. hedeften negatif sapma miktarı 
xj : j. karar değişkeni

$\tilde{a}_{i j}: \mathrm{j}$. karar değişkeninin i. hedefe katkısı (kullanım miktarı)

$b_{i}:$ i. bulanık hedef düzeyi

$\tilde{a}_{t j}:$ j. karar değişkeninin t. üretime katkısı (kaynağı kullanım miktar1)

$b_{\mathrm{t}}$ : t. bulanık kaynak (üretim) miktarı

Bulanık kümelerde kümenin elemanları [0,1] arasında değişen üyelik dereceleri $(\mu)$ alarak o kümeye dâhil olur. Eğer küme elemanı; 1 üyelik derecesi alıyorsa kümenin tam elemanıyken, 0 üyelik derecesi alıyorsa kümenin elemanı olamaz. Bu aralıkta aldıkları diğer değerler için ise farklı üyelik dereceleriyle bu kümeye ait olurlar. Bu yüzden Bulanık Küme Teorisi'nin esnek bir yaklaşımı olduğu söylenebilir. Üyelik fonksiyonu problemin durumuna göre birçok biçimde tanımlanabilir. $\mathrm{Bu}$ çalışmada kullanılan, alt ve üst sınır değerleri bilinen, doğrusal artan ve azalan üyelik fonksiyonlu $\mathrm{x}=\left(\mathrm{x}^{\mathrm{L}}, \mathrm{x}^{\mathrm{U}}\right)$ bulanık sayısı:

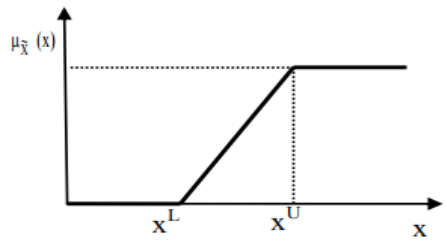

$$
\mathrm{x}=\mathrm{x}^{\mathrm{L}}+\left(\mathrm{x}^{\mathrm{U}}-\mathrm{x}^{\mathrm{L}}\right) \mu
$$

Şekil 1. Artan Üyelik Fonksiyonu

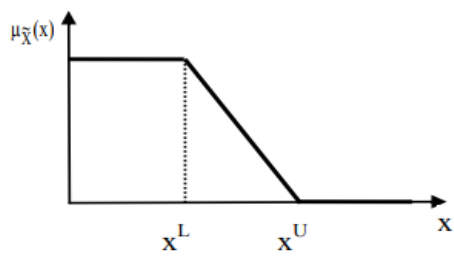

$\mathrm{x}=\mathrm{x}^{\mathrm{U}}-\left(\mathrm{x}^{\mathrm{U}}-\mathrm{x}^{\mathrm{L}}\right) \mu$

Şekil 2. Azalan Üyelik Fonksiyonu

Şeklinde tanımlanabilir. $(\mu)$ üyelik derecesine göre hesaplanan $(\mathrm{x})$ değeri, kesin değeri bilinen bir sayıdır. ( $\mu$ ) üyelik derecesi; hesaplanan (x) elemanının ( $\check{\mathrm{x}}$ ) bulanık kümesine ait olma derecesini ifade etmektedir (Oruç, 2014). 


\section{LITERATÜR TARAMASI}

Literatürde yapılan birçok çalışma vardır. Bu çalışmalar incelenmiş ve aşağıda örnek olarak verilmiştir.

Dağdeviren ve Eren (2001) Analitik Hiyerarşi Prosesi(AHP) ve 0-1 Hedef Programlama(HP) tekniklerinin genel yapısını anlatmış ve her iki yöntemi kullanarak tedarikçi seçimine yönelik bir uygulama yapmışlardır. Çıkan sonuçları karşılaştırmışlardır. Sonuçlara göre 0-1 HP kullanmak bu problem için daha iyi bir çözüm olduğu görülmüştür. Açık (2002) çalışmasında hedef programlama ile kurduğu model sayesinde, mevcut bir birliğin ya da belirlenen bir tehdide karşı yeniden teşkilatlandırılması gereken başka bir birliğin bu tehdidi bertaraf edip edemeyeceğini araştırmıştır. Dağdeviren vd. (2004) bu çalışmada iş değerlendirme sürecini anlatmış ve faktör derece puanlarının belirlenmesinde Hedef Programlama yönteminin kullanılabileceği bir uygulama göstermişlerdir. MESS tarafından belirlenen dokuz iş seçilmiş ve belirlenen kısıtlardaki sapma değerlerini en küçükleyemeyi amaçlamışlardır. Uygulama farklı kişilerin farklı önceliklere sahip olmasından dolayı oluşabilecek anlaşmazlıkları gidererek, bilimsel yöntemlerin kullanılmasını gerektirmektedir. Gülenç ve Karabulut (2005) çalışmalarında öncelikle Hedef Programlama Yöntemini tanıtarak Brisa A.Ş.'de yapılan bir uygulamaya yer vermişlerdir. Brisa A.Ş.'nin bir aylık üretim döneminde TBR sınıfı lastiklerden üretmesi gereken miktarları, kurulan Hedef Programlama Modelinin ABQM 3.0 Bilgisayar Programı ile çözülmesi sonucu bulmuşlardır. Kağnıcıoğlu ve Yıldız (2006) yaptıkları çalışmada, birden fazla amaç ve hedeflerde belirsizlik olması durumlarında, 01 Tam Sayılı Bulanık Hedef Programlama yaklaşımı ile atama problemlerinin çözümü için model önerisinde bulunmuşlardır. Uygulamada Dumlupınar Üniversitesi Endüstri Mühendisliği Bölümü sınavlarını ve sınav görevlilerini veri olarak kullanmışlardır. Daha önce sadece sayı bazında eşitlenmeye çalışılan atama problemini, artık sınav sürelerini de dikkate alarak eşit bir dağıtım ile sağlamaya çalışmışlardır. Karaman ve Kale (2007) inşaat projelerinin süre-maliyet-kalite açısından nasıl bir ilişki içerisinde olduğunu bulanık hedef programlama yöntemini 
kullanarak ortaya koymuşlardır. $\mathrm{Bu}$ yöntem ile örnek inşaat projesine ilişkin hedef fonksiyonları optimize etmişlerdir. Hesaplamalarda hedef fonksiyonların önem derecelerini de göz önüne almışlardır. Atılan (2008) Adana Bölgesinde bulunan ve toplu beslenme hizmetinin farklı yemek fabrikaları tarafindan verildiği 6 kurumun (tekstil fabrikası) yemekhanelerinde yürütülen bu çalışmada; farklı mevsimlere ait birer aylık öğlen yemeği menülerinin enerji ve besin öğeleri hesaplanmış, bireylerin gereksinim durumlarına uygunluk durumu incelenmiştir. Çalışma sonucunda önerilerde bulunulmuştur. Erdin (2008) içme suyu üretimi için korunan doğal bir havzanın toprak örtüsüne müdahale edilmesi durumunda su kalitesindeki değişiklikleri, bulanık hedef programlama teknikleri ile değerlendirmiştir. Çalışma içme suyu sağlanması amaciyla işletilen havzalarda bulanık hedef programlamanın etkin uygulama alanı bulacağını göstermektedir. Vatansever (2008) ayakkabı üreten bir firmanın üretim planını bulanık hedef programlama ile belirlemiştir. Elde edilen sonuçları mevcut durum planı ile karşılaştırmıştır ve artı değer sağlayan birçok yönü olduğunu ortaya koymuştur. Bilge (2009) Edirne'deki bir tekstil fabrikasında çalışan 138 kadın işçinin genel beslenme alışkanlıkları, antropometrik ölçümleri, bir günlük besin tüketimleri ve enerji harcamaları incelenmiştir. İncelemeler sonucunda değerlendirmeler yapılmıştır. Çalışkan ve Sungur (2009) çalışmalarında Kayan Süreli Esnek Çalışma Saati Modelini uygulayan işletmelerin tur çizelgeleme problemlerini çözmek üzere bir Karma Tam Sayılı Amaç Programlama Modeli geliştirmişlerdir. Optimum çözüme ulaşma sürecine katkısı sağlamışlardır. Ediz ve Yağdıran (2009) çalışmalarında 179 çeşit yemekten yararlanarak orta aktivite gerektiren iş faaliyetinde çalışan $19-30$ yaş aralığındaki çalışanlar için 15 günlük menü listelerini tam sayılı hedef programlama yöntemini kullanarak oluşturmuşlardır. Girginer ve Kaygısız (2009) yaptıkları çalışmada; yaygın kullanımı olan üç yazılım seçeneğini, her birisi alt kriterler içeren beş temel kritere göre AHP ile değerlendirmişlerdir. Elde edilen öncelikleri, kurulan 0-1 HP modeline öncelik kısıtı olarak dâhil etmişler ve iki yöntemin sonuçlarını karşılaştırmışlardır. Seljak (2009) çalışmasında menü planlamayı birkaç alt sisteme ayırarak bütün olasılıkları incelemeksizin, en uygun hedef fonksiyonların değerleri ile mümkün olan çeşitli çözümleri bilgisayara dayalı yöntemle belirlemiş ve incelemiştir. Akdeniz ve Aras (2010) İzmir'de bir 
plastik işletmesinde optimal hedeflere ulaşmak için bulanık hedef programlama kullanmışlardır. Çalışma sonucunda karar vericinin hedefleri ile modelin çıktıları arasındaki ilişki net olarak değerlendirilmiştir. Ekinci (2010) çalışmasında, otel işletmelerinde menü planlaması, menü fiyatlandırma yöntemleri ve çalışmalarının önemi, amac1, etkileri, neden ve nasıl yapılması gerektiği ile İstanbul Sürmeli Otelinde bir uygulama gerçekleştirmiştir. Erpolat (2010) bu çalışmada belirlenen bir piliç fabrikasındaki üretimi ele almıştır. Çözümde Hedef Programlama ve bulanık hedef programlama yöntemlerini kullanmıştır. Sonuçlara göre en uygun çözümün doğrusal üyelik fonksiyonlu bulanık hedef programlama yöntemi olduğu görülmüştür. Güngör vd. (2011) Üniversite harcamalarının akıllıca yapılması adına Hedef Programlama ve bulanık hedef programlama ile modeller kurmuşlar ve iki yöntemin etkinliklerini karşılaştırmışlardır. Model önerileri yaklaşık olarak birbirine yakındır. Karadağ ve Türkbey (2011) Ele aldıkları de montaj hattı dengeleme probleminde çalışma durumu ve ortamına göre öncelikli ve bulanık hedef programlama yöntemlerini kullanmışlardır. Çevrim zamanı, istasyon sayısı ve istasyonlardaki iş yükü dikkate alınan hedeflerdir Karar vericiye farklı alternatifleri değerlendirebilme imkânı sunmuşlardır. Şenol (2011) yaptığ 1 çalışmasını karma tam sayılı programlama modeli ile 19-30 yaş arası işçiler için menü oluşturmak amacıyla planlamış ve yürütmüştür. Araştırmada bu işçiler için set-seçimsiz, 3, 4 veya 5 kaplı, üç öğünlük (kahvaltı, öğle yemeği ve akşam yemeği), dört mevsimlik, dört ayrı menü modeli geliştirilmiştir. Körpeli vd. (2012) çalışmalarında Hedef Programlama Yöntemi kullanarak Kırıkkale Üniversitesi'nde örnek bir menü planlaması yapmışlardır. Elde edilen sonuçlar incelendiğinde; mevcut sistemde iyileşme olduğu ve daha düzenli hale geldiği gözlemlenmiştir. Orhan vd. (2012) yaptıkları çalışmada, uçak rotalarının belirlenmesi probleminin bakım gereksinimleri ile birlikte ele alınmasını, böylece uçakların etkin kullanımının yanı sıra bakım maliyetlerinin en küçüklenmesini hedeflemişlerdir. Belirtilen amaç doğrultusunda, bir tam sayılı doğrusal hedef programlama yaklaşımı önermişlerdir. Sarıkaya vd. (2012) tedarik zinciri ağında çok ürünlü, çok aşamalı ve çok dönemli planlama modelini önermişlerdir. Kesin olmayan hedefler için bulanık hedef programlama kullanmışlardır. Karar vericiye sistematik bir çerçeve sunmuşlardır. Koşan (2013) menü analizinde geleneksel ve çağdaş 
yöntemleri karşılaştırmış ortaya çıkaracağı farklılıkların belirlenmesini amaçlamıştır. Faaliyet tabanlı maliyetleme (FTM) ile yapılan menü analizi neticesinde, klasik menü analizinden daha farklı sonuçlara ulaşılmış elde edilen bulguların stratejik amaçlı olarak daha etkin kullanılabileceği görülmüştür. Pang ve Hammond (2013) çalışmalarında doğrusal regresyon modelleri ve ki-kare testleri ile kalorilerin menüler üzerindeki etkinlik ve tüketici tercihlerini değerlendirmişlerdir. Frampton vd. (2014) kentsel ve kırsal alan çocuk bakım merkezleri arasındaki farkları dikkate almışlar ve çocuk bakım merkezindeki menülerde öğle yemeğinde sunulan gıdaların besin içeriğini belirlemişlerdir. Oruç (2014) yaptığ 1 çalışmada; bulanık hedef programlama kullanarak 19-30 yaş arası işçiler için, set-seçimsiz, 20 günlük öğle yemeği menü planlaması yapmıştır. Planlamanın hedef programlama ile yapılmasının, el ile yapılan bir planlamanın sebep olabileceği olası hataları ortadan kaldıracağını söylemiştir. Soria-Contreras vd. (2014) çalışmalarında dört haftalık bir menü planı için bireysel danışmanlık yaparak Tip-2 diyabet hastaları üzerinde uygulama yapmışlardır. Akay ve Sarışık (2015) çalışmalarında yiyecekiçecek sektöründe yer alan işletme yöneticilerinin menü planlaması ve menü analizine bakış açılarını ortaya koymuşlardır. Buna ek olarak, menü planlaması ve menü analizi uygulamalarının işletmelerde hangi düzeyde gerçekleştirildiğini belirlemek araştırmalarının ikincil amacıdır. Güçlü ve Özdemir (2015) Tekstil sektöründeki tedarik zincirine yönelik belirsizlikler için bulanık hedef programlama yönteminden yararlanmışlardır. Toplam maliyet ve geri dönen ürün miktarını minimize etmeye çalışmışlardır. Erdoğmuş vd. (2015) 0-1 Tam Sayılı Doğrusal Programlama (TDP), Doğrusal Hedef Programlama (DHP) ve Bulanık Doğrusal Programlama (BDP) tekniklerini diyet probleminin çözümünde kullanmışlardır. Çalışmalarında 19-30 yaş grubunda orta fiziksel aktiviteye sahip $65 \mathrm{~kg}$. ağırlığındaki sağlıklı erkeklere ilişkin bir diyet problemini menü planlama kapsamında ele almışlardır. Çözüm yöntemlerini değerlendirmişler ve araştırmacı ve uygulayıcılara önerilerde bulunmuşlardır. Öztürk (2015) bir kamu kuruluşuna ait gerçek bir tesis yeri seçimi için bulanık hedef programlama yönteminden yararlanmıştır. Bu yöntemi uygulaması ile en iyi alternatif tesis kurulum yeri ortaya konmuştur. Aksaraylı vd. (2016) çalışmalarında akademik performansı ölçmek için bir model önermişlerdir. Performans 
kriterleri olarak akademik faaliyetler; bilimsel yayın, proje, araştırma ve bildiri ele alınmıştır. Yöntem olarak bulanık hedef programlama kullanmışlardır. Baykasoğlu vd. (2016) menü planlama çalışmaları için çok sayıda faktörü eş zamanlı dikkate alan ve yıl boyunca kullanılabilen matematiksel programlama temelli bir karar destek sistemi tasarlamışlardır. Tasarlanan model ile birlikte başarılı bir değişim yönetimi gerçekleştirilmiştir. Benvenuti vd. (2016) çalışmalarında minimum düzeyde su tüketimi ya da az miktarda sera gazı emisyonu gerektiren, çevresel etkilerin az olduğu bir aylık öğle yemeği için menü oluşturmuşlardır. Ertuğrul ve Öztaş (2016) ders programını optimal şekilde oluşturabilmek için 0-1 Tam sayılı bulanık hedef programlama kullanmıştır. Sarucan vd. enerji talebinin kesin değerlerle belirlenememesi nedeniyle enerji talebini bulanık hedef programlama ile modellemişlerdir. Çalışma sonucunda Türkiye'nin birincil enerji kaynaklarının planlaması yapılmış ve bulunan sonuçlar yorumlanmıştır. Ünal ve Eren(2016) 24 saat hizmet veren bir devlet kurumunda nöbet çizelgeleme problemini ele almışlardır. Yöntem olarak hedef programlama ve hedef programlamanin ağırlıklarını belirlemek için de Analitik Hiyerarşi prosesini kullanmışlardır. Çalışma sonucunda hiçbir personele gün aşırı nöbet atanmamıştır.

Çalışmalar incelendiğinde menü planlaması ile ilgili yapılan ve bulanık hedef programlamayı kullanan çalışmalar olmasına rağmen farklıliklar mevcuttur. $\mathrm{Bu}$ farkl1liklar kullanılan hedefler ve problemin ele aldığ adet olmak üzere besin hedef değeri belirlenirken yapılan çalışmada bu sayı on ikidir. Ayrıca menü çalışmalarında hastanede diyabet, mide ve karaciğer hastalarına yönelik bir menü planlaması ile karşılaşılmamıştır ve çalışmayı farklı kılan en önemli özellik budur. Diğer çalışmalarda amaç fonksiyonlarında maliyet kullanılmıştır. Bu çalışmada ise maliyet göz ardı edilmiştir.

\section{BULANIK HEDEF PROGRAMLAMA ÍLE MENÜ PLANLAMA}

$\mathrm{Bu}$ çalışma, toplu beslenme alanı olan hastanelerde yiyecek hizmeti alan personel ve hastaların bulanık hedef programlama ile bir gün 
için öğle yemeği öğününün planlaması problemini ele almıştır. Yöntem olarak bulanık hedef programlama kullanılması alınması gereken besin değerlerindeki belirsizliği ortadan kaldırmaktır. $\mathrm{Bu}$ da bulanıklaştırılarak yani hedef değerlerin $\% 5$ 'i alınarak alt ve üst olmak üzere genişletilmesi ile oluşur. $\mathrm{Bu}$ değerin $\% 5$ olarak belirlenmesi her kap için porsiyonlarda oluşacak besin miktarlarının farklılık göstermesindendir(Oruç,2014). Eğer oran $\% 2$ olsaydı hedef değerin artış oranı az, \%10 olsaydı fazla olurdu. Kısacası bulanıklaştırma oranı arttıkça modelin esnekliği de artırılmakta fakat hedef değerlerden uzaklaşılmaktadır. Menü planlamasında on beş grup üzerinden yiyecek seçimi yapılmış dengeli bir dağıtım sağlanmaya çalışılmıştır. Belirlenen menüde kişinin günlük besin ögesi ihtiyaçlarının karşılanmasına dikkat edilmiştir. Menüler planlanırken kalori, karbonhidrat, protein, yağ, lif, kolesterol, sodyum, potasyum, kalsiyum, A Vitamini, C Vitamini ve demir dikkate alınan besin değerleridir. Elde edilen bu bilgiler ve uygulamada ulaşılması istenen sonuçlar uzman kişilerle ortaya konmuştur. Modelin çözümü için ILOG Paket Programı kullanılmıştır. ILOG Paket Programı optimizasyon ve matematiksel modellerin çözümünde kullanılan, analitik kararlar vermemizi sağlayan bir çözümleyicidir(www.ibm.com; 2009). Uygulama süreci Şekil.3’te verilen akış şeması ile gösterilmiştir.

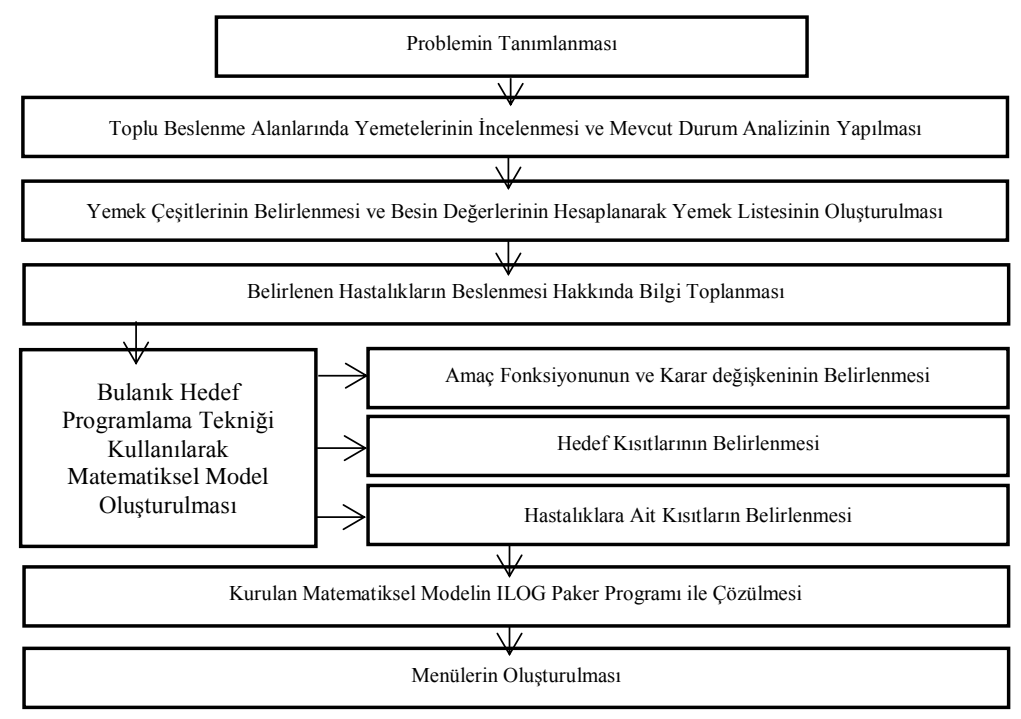

Şekil 3. Akış Şeması 
Toplu beslenmenin olduğu yerlerde menüler servisin seçmeli ve tabldot tipi olmasına göre üç kap veya daha fazla olarak oluşturulur. Bu çalışma için de hastane menüleri analiz edilmiş ve seçim 4 kap olarak belirlenmiştir. Bunlar Tablo.1'de verilmiştir.

Tablo 1. Kap

\begin{tabular}{|c|c|c|c|}
\hline \multicolumn{4}{|c|}{ YEMEKLER } \\
\hline 1.KAP & 2.KAP & 3.KAP & 4.KAP \\
\hline Çorbalar & $\begin{array}{c}\text { Etli Sebze Yemekleri } \\
\text { Köfteler } \\
\text { Tavuk Yemekleri } \\
\text { Balıklar } \\
\text { Etli Kurubaklagiller }\end{array}$ & $\begin{array}{c}\text { Pilavlar } \\
\text { Börekler } \\
\text { Zeytinyağlllar } \\
\text { Makarnalar }\end{array}$ & $\begin{array}{l}\text { Şerbetli Tatlılar } \\
\text { Sütlü Tatlılar } \\
\text { Meyveler } \\
\text { Salatalar } \\
\text { Diğer }\end{array}$ \\
\hline
\end{tabular}

Birinci kap yemekler çorba çeşitleridir. İkincisi Ana Yemeklerdir. Üçüncüsü Yan Yemeklerdir. Sonuncusu ise yemekleri tamamlayıcı olan seçeneklerdir. Listede bulunan yemeklerden bir öğünde birer porsiyon alınması gerekir. Tablo 2'de kap seçeneklerinde bulunan yemeklere bazı örnekler verilmiştir.

Tablo 2. Kaplarda Bulunan Bazı Yemekler

\begin{tabular}{|c|c|c|c|}
\hline 1.KAP & 2.KAP & 3.KAP & 4.KAP \\
\hline Domates Çorbası & Bahçevan Kebap & Sade Pirinç Pilavı & Baklava \\
Havuç Çorbası & Et Sote & Bulgur Pilavı & Şekerpare \\
Mısır Çorbası & İzmir Köfte & Milföy Böreği & Profiterol \\
Mantar Çorbası & Etli Sebze & Yeşil Mercimekli & Sütlü İrmik Tatlısı \\
Sebze Çorbası & Tavuk But Haşlama & Börek & Sütlaç \\
Brokoli Çorbası & Firında Piliç Pirzola & $\begin{array}{c}\text { Zeytinyağlı } \\
\text { Barbunya }\end{array}$ & Çoban Salata \\
Ispanak Çorbası & Etli Taze Fasulye & Auran \\
Lahana Çorbası & Kiymalı Bezelye & $\begin{array}{c}\text { Kurulye Piyazı } \\
\text { Vişne Kompostosu }\end{array}$ \\
\hline
\end{tabular}




\begin{tabular}{|c|c|c|c|}
\hline Bezelye Çorbası & Firında Balık & Zeytinyağlı Pırasa & Muz \\
Patates Çorbası & Etli Nohut & Zeytinyağlı & Elma \\
Şehriye Çorbası & & Karnabahar & Çilek \\
& & Fırında Makarna & \\
& & Erişte & \\
& & & \\
\hline
\end{tabular}

\subsection{Karar Değişkenlerinin ve Kısıtların Belirlenmesi}

Kurulan matematiksel modelde öncelikle karar değişkeni belirlenmiştir. Karar değişkeni listede yer alan yemekleri temsil etmektedir. Karar değişkeni belirlenirken kurulan modelin her gün için bir yemek seçimi yapması göz önünde tutulmuştur.

\section{Karar Değișkeni:}

$\mathbf{X}_{\mathbf{j k}}=\left\{\begin{array}{l}1 \text { j.yemeğin k.gün seçilmesi } \\ 0 \text { diğer durumlarda }\end{array}\right.$

$\mathrm{j}: 1,2, \ldots, 122$ (yemek say1s1)

$\mathrm{k}: 1,2, \ldots, 30$ (gün)

\section{Genel Kisitlar:}

Menüler oluşturulurken bazı hususlara dikkat etmek gerekir. Bunlar yemeklerin birbiri ile olan renk, tat, şekil ve kıvam bakımından uyumudur. Bu yüzden genel kısitlar hastane personelleri, diyabet, mide ve karaciğer hastalığı olan kişilerin hepsi için söz konusudur. 
1.Klsıt: Çorbalardan birinin seçilmesi;

$$
\sum_{j=1}^{32}\left(X_{j k}\right)=1 \quad \mathrm{k}=1,2,3, \ldots, 30
$$

2.Kısıt: Ana yemeklerden birinin seçilmesi;

$$
\sum_{j=33}^{71}\left(X_{j k}\right)=1 \quad \mathrm{k}=1,2,3, \ldots, 30
$$

3.Kısıt: Yan yemeklerden birinin seçilmesi;

$$
\sum_{j=72}^{89}\left(X_{j k}\right)=1 \quad \mathrm{k}=1,2,3, \ldots, 30
$$

4.Klsıt: Seçeneklerden birinin seçilmesi;

$$
\sum_{j=90}^{122}\left(X_{j k}\right)=1 \quad \mathrm{k}=1,2,3, \ldots, 30
$$

5.Klsıt: Balık yemeklerinin, sütlü ve yoğurtlu çorbaların, mantı, sütlü tatlıların, akdeniz salatanın ve diğerlerinin birlikte olmaması;

$\sum_{j=4}^{5}\left(X_{j k}\right)+\sum_{j=7}^{10}\left(X_{j k}\right)+\sum_{j=14}^{22}\left(X_{j k}\right)+\sum_{j=24}^{26}\left(X_{j k}\right)+X_{29 k}+$ $X_{46 k}+X_{52 k}+X_{57 k}+$

$\sum_{j=60}^{67}\left(X_{j k}\right)++X_{85 k}+X_{89 k}+\sum_{j=94}^{104}\left(X_{j k}\right)+\sum_{j=118}^{119}\left(X_{j k}\right)+$

$\sum_{j=121}^{122}\left(X_{j k}\right) \leq 1 \quad \mathrm{k}=1,2,3, \ldots, 30$

6.Kısıt: Keşkek, pilav, makarna, börek, mantı ve zeytinyağlı sarmanın birlikte verilmemesi;

$X_{70 k}+\sum_{j=72}^{74}\left(X_{j k}\right)+\sum_{j=85}^{89}\left(X_{j k}\right)+\sum_{j=75}^{78}\left(X_{j k}\right)+X_{46 k}+X_{81 k} \leq 1$ $\mathrm{k}=1,2,3, \ldots, 30$

7.Klsıt: Börek, mantı, sütlü ve şerbetli tatlların bir arada olmamasl;

$$
\sum_{j=75}^{78}\left(X_{j k}\right)+\sum_{j=94}^{104}\left(X_{j k}\right)+\sum_{j=90}^{93}\left(X_{j k}\right)+X_{46 k} \leq 1
$$

$\mathrm{k}=1,2,3, \ldots, 30$

8.Kıstt: Bazı etli sebze yemeklerinin, bazı zeytinyağllların ve akdeniz salatanin birlikte verilmemesi; 
$\sum_{j=33}^{34}\left(X_{j k}\right)+X_{36 k}+\sum_{j=41}^{42}\left(X_{j k}\right)+X_{44 k}+\sum_{j=81}^{84}\left(X_{j k}\right)+X_{118 k} \leq 1$

$\mathrm{k}=1,2,3, \ldots, 30$

9.Kısıt: Tavuk çorbalarının, tavuk yemeklerinin, köftelerin ve balıklarin birlikte verilmemesi;

$$
\underset{\mathrm{k}=1,2,3, \ldots, 30}{\sum_{j=18}^{21}\left(X_{j k}\right)+\sum_{j=52}^{59}\left(X_{j k}\right)+\sum_{j=47}^{51}\left(X_{j k}\right)+\sum_{j=60}^{67}\left(X_{j k}\right) \leq 1}
$$

10.Kısıt: Yoğurt çorbalarının, mantı, sütlü tatlıların ve diğerlerinin birlikte verilmemesi;

$$
\underset{\mathrm{k}=1,2,3, \ldots, 30}{\sum_{j=14}^{17}\left(X_{j k}\right)+X_{46 k}+\sum_{j=94}^{104}\left(X_{j k}\right)+\sum_{j=119}^{122}\left(X_{j k}\right) \leq 1}
$$

11.Klsit: Etli kurubaklagil yemekleri ile zeytinyağll yemeklerin bir arada verilmemesi;

$\mathrm{k}=1,2,3, \ldots, 30$

$$
\sum_{j=68}^{71}\left(X_{j k}\right)+\sum_{j=79}^{84}\left(X_{j k}\right) \leq 1
$$

12.Klsit: Köfte ve böreğin birlikte olmaması;

$\mathrm{k}=1,2,3, \ldots, 30$

$$
\sum_{j=47}^{51}\left(X_{j k}\right)+\sum_{j=75}^{78}\left(X_{j k}\right) \leq 1
$$

13.Kısıt: Makarna salatası, köri soslu tavuk, beşamel soslu tavuk, firında makarna, sütlü tatlılar ve diğerlerinin birlikte olmaması;

$$
\begin{gathered}
X_{85 k}+X_{89 k}+X_{52 k}+X_{57 k}+\sum_{j=94}^{104}\left(X_{j k}\right)+X_{119 k}+ \\
\sum_{j=121}^{122}\left(X_{j k}\right) \leq 1
\end{gathered}
$$

$\mathrm{k}=1,2,3, \ldots, 30$

14.Klsit: Balıkların ve zeytinyağll yaprak sarmanın birlikte olmamasl;

$\mathrm{k}=1,2,3, \ldots, 30$

$$
\sum_{j=60}^{67}\left(X_{j k}\right)+X_{81 k} \leq 1
$$

15.Klsıt: Bazl etli sebze yemekleriyle sebze çorbalarının birlikte olmamast;

$$
\underset{\mathrm{k}=1,2,3, \ldots, 30}{\sum_{j=1}^{11}\left(X_{j k}\right)+\sum_{j=33}^{34}\left(X_{j k}\right)+X_{37 k}+X_{39 k}+X_{41 k}+X_{45 k} \leq 1}
$$


16.Kısıt: Zeytinyağll yemeklerin ve bazı balı yemeklerinin birlikte olmamasi;

$\mathrm{k}=1,2,3, \ldots, 30$

$$
\sum_{j=79}^{84}\left(X_{j k}\right)+X_{63 k}+X_{65 k} \leq 1
$$

17.Klsit: Mercimekli yemeklerin birlikte olmamasl;

$$
\begin{gathered}
\left(X_{29 k}\right)+\left(X_{30 k}\right)+\left(X_{31 k}\right)+\left(X_{32 k}\right)+\left(X_{51 k}\right)+\left(X_{71 k}\right)+ \\
\left(X_{77 k}\right) \leq 1
\end{gathered}
$$

$\mathrm{k}=1,2,3, \ldots, 30$

18.Klsit: Şehriyeli yemeklerin birlikte olmamasl;

$\mathrm{k}=1,2,3, \ldots, 30$

$$
\left(X_{23 k}\right)+\left(X_{74 k}\right) \leq 1
$$

19.Klsit: Bulgurlu yemeklerin birlikte olmamasl;

$$
\left(X_{24 k}\right)+\left(X_{27 k}\right)+\left(X_{73 k}\right)+\left(X_{49 k}\right)+\left(X_{51 k}\right)+\left(X_{81 k}\right) \leq 1
$$

$\mathrm{k}=1,2,3, \ldots, 30$

20.Kısit: Patatesli yemeklerin birlikte olmaması;

$$
\left(X_{12 k}\right)+\left(X_{35 k}\right)+\left(X_{38 k}\right)+\left(X_{40 k}\right)+\left(X_{47 k}\right)+\left(X_{48 k}\right)+
$$

$$
\left(X_{78 k}\right) \leq 1
$$

$\mathrm{k}=1,2,3, \ldots, 30$

21.Kısıt: Hamurlu yemeklerin birlikte olmaması;

$$
\begin{gathered}
\left(\mathrm{X}_{29 \mathrm{k}}\right)+\left(\mathrm{X}_{46 \mathrm{k}}\right)+\left(\mathrm{X}_{75 \mathrm{k}}\right)+\left(\mathrm{X}_{76 \mathrm{k}}\right)+\left(\mathrm{X}_{77 \mathrm{k}}\right)+\left(\mathrm{X}_{78 \mathrm{k}}\right)+\left(\mathrm{X}_{85 \mathrm{k}}\right) \\
+\left(\mathrm{X}_{86 \mathrm{k}}\right)+\left(\mathrm{X}_{87 \mathrm{k}}\right)+\left(\mathrm{X}_{88 \mathrm{k}}\right)+\left(\mathrm{X}_{89 \mathrm{k}}\right) \leq 1
\end{gathered}
$$

$\mathrm{k}=1,2,3, \ldots, 30$

22.Kısıt: Fasulyeli yemeklerin birlikte olmamasl;

$$
\begin{array}{r}
\left(X_{13 k}\right)+\left(X_{34 k}\right)+\left(X_{37 k}\right)+\left(X_{69 k}\right)+\left(X_{79 k}\right)+\left(X_{80 k}\right)+ \\
\mathrm{k}=1,2,3, \ldots ., 30
\end{array}
$$




\section{Sapma Değiskenleri}

Bulanık hedef programlama birden fazla hedefin aynı anda gerçekleşmesini sağlamaktadır. Sapma miktarları belirlenen hedef değerlerinden ne kadar fazla ya da eksik olduğunun göstergesidir.

$\mathrm{k}_{\mathrm{k}}{ }^{-}=\mathrm{k}$. günde alınan kalori miktarı hedefinden negatif sapma $\mathrm{k}_{\mathrm{k}}^{+}=\mathrm{k}$. günde alınan kalori miktarı hedefinden pozitif sapma $\mathrm{kh}_{\mathrm{k}}{ }^{-}=\mathrm{k}$. günde alınan karbonhidrat miktarı hedefinden negatif sapma

$\mathrm{kh}_{\mathrm{k}}{ }^{+}=\mathrm{k}$. günde alınan karbonhidrat miktarı hedefinden pozitif sapma

$\mathrm{p}_{\mathrm{k}}{ }^{-}=\mathrm{k}$. günde alınan protein miktarı hedefinden negatif sapma

$\mathrm{p}_{\mathrm{k}}{ }^{+}=\mathrm{k}$. günde alınan protein miktarı hedefinden pozitif sapma

$\mathrm{y}_{\mathrm{k}}{ }^{-}=\mathrm{k}$. günde alınan yağ miktarı hedefinden negatif sapma

$\mathrm{y}_{\mathrm{k}}{ }^{+}=\mathrm{k}$. günde alınan yağ miktarı hedefinden pozitif sapma

$\mathrm{l}_{\mathrm{k}}{ }^{-}=\mathrm{k}$. günde alınan lif miktarı hedefinden negatif sapma

$\mathrm{l}_{\mathrm{k}}{ }^{+}=\mathrm{k}$. günde alınan lif miktarı hedefinden pozitif sapma

$\mathrm{ko}_{\mathrm{k}}{ }^{-}=\mathrm{k}$. günde alınan kolesterol miktarı hedefinden negatif sapma

$\mathrm{ko}_{\mathrm{k}}{ }^{+}=\mathrm{k}$. günde alınan kolesterol miktarı hedefinden pozitif sapma

$\mathrm{s}_{\mathrm{k}}{ }^{-}=\mathrm{k}$. günde alınan sodyum miktarı hedefinden negatif sapma

$\mathrm{S}_{\mathrm{k}}{ }^{+}=\mathrm{k}$. günde alınan sodyum miktarı hedefinden pozitif sapma

$\mathrm{po}_{\mathrm{k}}{ }^{-}=\mathrm{k}$. günde alınan potasyum miktarı hedefinden negatif sapma

$\mathrm{po}_{\mathrm{k}}{ }^{+}=\mathrm{k}$. günde alınan potasyum miktarı hedefinden pozitif sapma

$\mathrm{ka}_{\mathrm{k}}{ }^{-}=\mathrm{k}$. günde alınan kalsiyum miktarı hedefinden negatif sapma

$\mathrm{ka}_{\mathrm{k}}{ }^{+}=\mathrm{k}$. günde alınan kalsiyum miktarı hedefinden pozitif sapma

$\mathrm{vA}_{\mathrm{k}}{ }^{-}=\mathrm{k}$. günde alınan vitamin A miktarı hedefinden negatif sapma

$\mathrm{vA}_{\mathrm{k}}{ }^{+}=\mathrm{k}$. günde alınan vitamin A miktarı hedefinden pozitif sapma

$\mathrm{vC}_{\mathrm{k}}{ }^{-}=\mathrm{k}$. günde alınan vitamin $\mathrm{C}$ miktarı hedefinden negatif sapma

$\mathrm{vC}_{\mathrm{k}}{ }^{+}=\mathrm{k}$. günde alınan vitamin $\mathrm{C}$ miktarı hedefinden pozitif sapma 
$\mathrm{d}_{\mathrm{k}}{ }^{-}=\mathrm{k}$. günde alınan demir miktarı hedefinden negatif sapma $\mathrm{d}_{\mathrm{k}}^{+}=\mathrm{k}$. günde alınan demir miktarı hedefinden pozitif sapma

\section{Hedef Kisitları}

Menü planlanırken kalori, karbonhidrat, protein, yăg, lif, kolesterol, sodyum, potasyum, kalsiyum, vitamin-A, vitamin-C ve demir değerleri dikkate alınarak hedef kısıtları belirlenmiştir. Hedef kısıtlarının belirlenmesinde başta temel besin ögeleri olmak üzere beslenmede önemli grupların alınmasına dikkat edilmiştir. $\mathrm{Bu}$ gruplar ve değerler ise uzman kişilerden alınan bilgiler doğrultusunda oluşturulmuştur. Tablo.6'da bir günde öğle yemeğinde alınması gereken besin değerleri verilmiştir. Tablodaki hedefler artan üyelik fonksiyonuna göre hesaplanarak sağ taraf değerleri oluşturulmuştur.

Tablo 6.Bir Günde Öğle Yemeğinde Alınması Gereken Besin Değerleri

\begin{tabular}{|c|c|c|c|c|c|}
\hline $\begin{array}{c}\text { Besin } \\
\text { değerleri }\end{array}$ & Hedef & $\begin{array}{c}\text { Besin } \\
\text { değerleri }\end{array}$ & Hedef & $\begin{array}{c}\text { Besin } \\
\text { değerleri }\end{array}$ & Hedef \\
\hline Kalori(kkal) & 700 & Lif(gr) & 25 & $\begin{array}{c}\text { Kalsiyum( } \\
\text { mgr) }\end{array}$ & 500 \\
\hline $\begin{array}{c}\text { Karbonhidra } \\
\text { t(gr) }\end{array}$ & 90 & $\begin{array}{c}\text { Kolesterol( } \\
\mathbf{m g})\end{array}$ & 120 & $\begin{array}{c}\text { Vitamin } \\
\text { A(mcg) }\end{array}$ & 900 \\
\hline Protein(gr) & 40 & $\begin{array}{c}\text { Sodyum(m } \\
\text { g) }\end{array}$ & 800 & $\begin{array}{c}\text { Vitamin } \\
\text { C(mgr) }\end{array}$ & 50 \\
\hline Yağ(gr) & 25 & $\begin{array}{c}\text { Potasyum( } \\
\mathbf{m g r})\end{array}$ & 1500 & $\begin{array}{c}\text { Demir(mg } \\
\mathbf{r})\end{array}$ & 9 \\
\hline
\end{tabular}

Kalori Kısıtı: Her gün öğle yemeğinde alınması gereken kalori miktarl; 
$\mathrm{k}=1,2,3, \ldots, 30$

$$
\sum_{j=1}^{122}\left(X_{j k}\right) * \text { kalori }+\mathrm{k}^{-}-\mathrm{k}^{+} \geq 735
$$

Karbonhidrat Kısıtı: Her gün öğle yemeğinde alınması gereken karbonhidrat miktart;

$\mathrm{k}=1,2,3, \ldots, 30$

$$
\sum_{j=1}^{122}\left(X_{j k}\right) * \text { karbonhidrat }+\mathrm{kh}^{-}-\mathrm{kh}^{+} \geq \mathbf{9 4 . 5}
$$

Protein Kısıtı: Her gün öğle yemeğinde alınması gereken protein miktarl;

$\mathrm{k}=1,2,3, \ldots, 30$

$$
\sum_{j=1}^{122}\left(X_{j k}\right)^{*} \text { protein }+\mathrm{p}^{-}-\mathrm{p}^{+} \geq \mathbf{4 2}
$$

Yă̆ Kısıtı: Her gün öğle yemeğinde alınması gereken yă̆ miktarı;

$\mathrm{k}=1,2,3, \ldots, 30$

$$
\sum_{j=1}^{122}\left(X_{j k}\right) * \mathrm{yag}^{-} \mathrm{y}^{-}-\mathrm{y}^{+} \geq \mathbf{2 6 . 2 5}
$$

Lif Kısıtı: Her gün öğle yemeğinde alınması gereken lif miktarı;

$$
\sum_{j=1}^{122}\left(X_{j k}\right) * 1 \text { if }+1^{-}-1^{+} \geq \mathbf{2 6 . 2 5}
$$

$\mathrm{k}=1,2,3, \ldots, 30$

Kolesterol Kısıtı: Her gün öğle yemeğinde alınması gereken kolesterol miktarl;

$\mathrm{k}=1,2,3, \ldots, 30$

$$
\sum_{j=1}^{122}\left(X_{j k}\right) * \text { kolesterol+ko- }-\mathrm{ko}^{+} \geq \mathbf{1 2 6}
$$

Sodyum Kısıtı: Her gün öğle yemeğinde alınması gereken sodyum miktarl;

$\mathrm{k}=1,2,3, \ldots, 30$

$$
\sum_{j=1}^{122}\left(X_{j k}\right) * \text { sodyum }+\mathrm{s}^{-}-\mathrm{s}^{+} \geq \mathbf{8 4 0}
$$

Potasyum Kısıtı: Her gün öğle yemeğinde alınması gereken potasyum miktarl;

$\mathrm{k}=1,2,3, \ldots, 30$

$$
\sum_{j=1}^{122}\left(X_{j k}\right) * \text { potasyum }+ \text { po }^{-}-\text {po }^{+} \geq \mathbf{1 5 7 5}
$$

Kalsiyum Kısıtı: Her gün öğle yemeğinde alınması gereken kalsiyum miktarl; 
$\mathrm{k}=1,2,3, \ldots, 30$

$$
\sum_{j=1}^{122}\left(X_{j k}\right) * \text { kalsiyum }+\mathrm{ka}^{-}-\mathrm{ka}^{+} \geq \mathbf{5 2 5}
$$

Vitamin-A Kısıtı: Her gün öğle yemeğinde alınması gereken vitamin-A miktarl;

$\mathrm{k}=1,2,3, \ldots, 30$

$$
\sum_{j=1}^{122}\left(X_{j k}\right) * \text { vitamin } \mathrm{A}+\mathrm{vA}^{-}-\mathrm{vA}^{+} \geq \mathbf{9 4 5}
$$

Vitamin-C Kısıtı: Her gün öğle yemeğinde alınması gereken vitamin-C miktarl;

$\mathrm{k}=1,2,3, \ldots, 30$

$$
\sum_{j=1}^{122}\left(X_{j k}\right) * v i t a m i n C+v C^{-}-\mathrm{vC}^{+} \geq \mathbf{5 2 . 5 0}
$$

Demir Kısıtı: Her gün öğle yemeğinde alınması gereken demir miktarl;

$$
\sum_{j=1}^{122}\left(X_{j k}\right) * \text { demir }+\mathrm{d}^{-}-\mathrm{d}^{+} \geq \mathbf{9 . 4 5}
$$

$\mathrm{k}=1,2,3, \ldots, 30$

\section{Hastalık Kisıtları}

Diyabet, mide ve karaciğer hastalarının beslenmeleri hakkında araştırma yapılmış ve uzman kişilerden bilgiler alınmıştır. Bu bilgiler dahilinde her hastalık için yasaklı yiyecekler belirlenerek hastaların yemek listelerinden çıkarılmıştır. Menüler her hastalık için yasaklı yiyecekler çıkarıldıktan sonra çözülmüştür.

\section{Diyabet Hastaları}

Diyabet hastaları; bezelye çorbası, pirinç çorbası, mant1, sade pirinç pilavi, şehriyeli pilav, su böreği, yeşil mercimekli börek, patatesli börek, zeytinyağlı yaprak sarma, makarnalar grubu, şerbetli ve sütlü tatlılar, üzüm, karpuz ve vişne kompostosunu yememelidirler. $\mathrm{Bu}$ yemeklerin matematiksel modelde kullanılan sayısal ifadesi aşağıda verilmiştir.

Çorbalar 
$\mathrm{k}=1,2,3, \ldots, 30$

$$
\left(X_{11 k}\right)+\left(X_{26 k}\right)=0
$$

Ana Yemekler

$\mathrm{k}=1,2,3, \ldots, 30$

$$
\left(X_{46 k}\right)=0
$$

Yan Yemekler

$$
\left(X_{72 k}\right)+\left(X_{74 k}\right)+\sum_{j=76}^{78}\left(X_{j k}\right)+\sum_{j=85}^{89}\left(X_{j k}\right)+\left(X_{81 k}\right)=0
$$

$\mathrm{k}=1,2,3, \ldots, 30$

Seçenekler

$\mathrm{k}=1,2,3, \ldots ., 30$

$$
\sum_{j=90}^{105}\left(X_{j k}\right)+\sum_{j=111}^{112}\left(X_{j k}\right)+\left(X_{120 k}\right)=0
$$

\section{Mide Hastaları}

Mide hastaları; domates çorbası, lahana çorbası, kremalı tavuk çorbası, zerdeçallı tavuk çorbası, patlıcan musakka, ekşili köfte, mercimekli köfte, köri soslu tavuk, beşamel soslu tavuk, hamsi, çıtır balık, etli kurubaklagil grubu, sade pirinç pilavı, şehriyeli pilav, börekler, zeytinyağlı barbunya, kuru fasulye piyazı, zeytinyağlı karnabahar, firında makarna, makarna salatası, şerbetli tatlılar, aşure, profiterol, trileçe, etimek, tiramisu, supangle, kakaolu puding, sütlaç, limonlu irmik tatlısı, çilek, portakal ve salata grubunu yememelidirler. $\mathrm{Bu}$ yemeklerin matematiksel modelde kullanılan sayısal ifadesi aşağıda verilmiştir.

Çorbalar

$$
\mathrm{k}=1,2,3, \ldots, 30
$$

$$
\left(X_{1 k}\right)+\left(X_{10 k}\right)+\sum_{j=20}^{21}\left(X_{j k}\right)=0
$$

Ana Yemekler

$$
\underset{\mathrm{k}=1,2,3, \ldots ., 30}{\left(X_{36 k}\right)+\sum_{j=50}^{52}\left(X_{j k}\right)+\left(X_{57 k}\right)+\left(X_{61 k}\right)+\sum_{j=67}^{71}\left(X_{j k}\right)=0}
$$

Yan Yemekler 


$$
\begin{aligned}
\left(X_{72 k}\right)+\left(X_{74 k}\right)+\sum_{j=75}^{80}\left(X_{j k}\right)+\sum_{j=84}^{85}\left(X_{j k}\right)+\left(X_{89 k}\right)=0 \\
\mathrm{k}=1,2,3, \ldots, 30
\end{aligned}
$$

Seçenekler

$$
\begin{gathered}
\sum_{j=90}^{96}\left(X_{j k}\right)+\sum_{j=98}^{100}\left(X_{j k}\right)+\sum_{j=102}^{104}\left(X_{j k}\right)+\left(X_{107 k}\right)+\left(X_{110 k}\right)+ \\
\sum_{j=116}^{118}\left(X_{j k}\right)=0 \\
\mathrm{k}=1,2,3, \ldots, 30
\end{gathered}
$$

\section{Karaciğer Hastaları}

Karaciğer hastaları; yoğurt çorbası, düğün çorbası, soğuk ayran çorbası, yayla çorbası, tavuk suyu çorbası, tavuk çorbası, kremalı tavuk çorbası, zerdeçallı tavuk çorbası, buğday unu çorbası, bulgur çorbası, pirinç çorbası, mengen çorbası, yeşil mercimek çorbası, mercimek çorbası, patlıcan musakka, ekşili köfte, mercimekli köfte, köri soslu tavuk, beşamel soslu tavuk, hamsi, çıtır balık, etli kurubaklagil grubu, bulgur pilavı, yeşil mercimekli börek, zeytinyağlı barbunya, kuru fasulye piyazı, zeytinyağlı yaprak sarma, makarna salatası, şerbetli tatlılar, aşure, profiterol, tiramisu, supangle ve kakaolu puding yememelidirler. $\mathrm{Bu}$ yemeklerin matematiksel modelde kullanılan sayısal ifadesi aşağıda verilmiştir.

Çorbalar

$$
\underset{\mathrm{k}=1,2,3, \ldots, 30}{\sum_{j=14}^{22}\left(X_{j k}\right)+\left(X_{24 k}\right)+\sum_{j=26}^{27}\left(X_{j k}\right)+\sum_{j=30}^{31}\left(X_{j k}\right)=0}
$$

Ana Yemekler

$$
\begin{aligned}
&\left(X_{36 k}\right)+\sum_{j=50}^{52}\left(X_{j k}\right)+\left(X_{57 k}\right)+\left(X_{61 k}\right)+\sum_{j=67}^{71}\left(X_{j k}\right)=0 \\
& \mathrm{k}=1,2,3, \ldots ., 30
\end{aligned}
$$

Yan Yemekler

$$
\mathrm{k}=1,2,3, \ldots, 30
$$

$$
\left(X_{73 k}\right)+\left(X_{77 k}\right)+\sum_{j=79}^{81}\left(X_{j k}\right)+\left(X_{89 k}\right)=0
$$

Seçenekler

$$
\mathrm{k}=1,2,3, \ldots, 30
$$

$$
\sum_{j=90}^{95}\left(X_{j k}\right)+\sum_{j=99}^{100}\left(X_{j k}\right)+\left(X_{102 k}\right)=0
$$




\section{Gün Kısıtları}

Yemek listesindeki yemeklerin modelin çözüm sonucunda ard arda veya sık aralıklarla çıkmaması için en az kaç gün ara ile çıkacağı belirleyen kisitlardır.

Her çorbanın dört günde bir çıkması kısıtı;

$$
\sum_{j=1}^{32}\left(X_{j k}\right)+\sum_{j=1}^{32}\left(X_{J(k+1)}\right)+\sum_{j=1}^{32}\left(X_{J(k+2)}\right)+\sum_{j=1}^{32}\left(X_{J(k+3)}\right) \leq 1
$$

$\mathrm{k}=1,2,3, \ldots, 27$

Her etli sebze yemeğinin dört günde bir çıkması kısıtı;

$$
\sum_{j=33}^{46}\left(X_{j k}\right)+\sum_{j=33}^{46}\left(X_{J(k+1)}\right)+\sum_{j=33}^{46}\left(X_{J(k+2)}\right)+\sum_{j=33}^{46}\left(X_{J(k+3)}\right) \leq 1
$$

$\mathrm{k}=1,2,3, \ldots, 27$

Her köfte yemeğinin dört günde bir çıkması kısıtı;

$$
\sum_{j=47}^{51}\left(X_{j k}\right)+\sum_{j=47}^{51}\left(X_{J(k+1)}\right)+\sum_{j=47}^{51}\left(X_{J(k+2)}\right)+\sum_{j=47}^{51}\left(X_{J(k+3)}\right) \leq 1
$$

$\mathrm{k}=1,2,3, \ldots, 27$

Her tavuk yemeğinin dört günde bir çıkması kısıtı;

$$
\sum_{j=52}^{59}\left(X_{j k}\right)+\sum_{j=52}^{59}\left(X_{J(k+1)}\right)+\sum_{j=52}^{59}\left(X_{J(k+2)}\right)+\sum_{j=52}^{59}\left(X_{J(k+3)}\right) \leq 1
$$

$\mathrm{k}=1,2,3, \ldots, 27$

Her balık yemeğinin altı günde bir çıkması kısıtı;

$$
\begin{gathered}
\sum_{j=60}^{67}\left(X_{j k}\right)+\sum_{j=60}^{67}\left(X_{J(k+1)}\right)+\sum_{j=60}^{67}\left(X_{J(k+2)}\right)+ \\
\sum_{j=60}^{67}\left(X_{J(k+3)}\right)+\sum_{j=60}^{67}\left(X_{J(k+4)}\right)+\sum_{j=60}^{67}\left(X_{J(k+5)}\right) \leq 1
\end{gathered}
$$

$\mathrm{k}=1,2,3, \ldots, 25$

Her kuru baklagil yemeğinin dört günde bir çıkması kısıtı;

$$
\sum_{j=68}^{71}\left(X_{j k}\right)+\sum_{j=68}^{71}\left(X_{J(k+1)}\right)+\sum_{j=68}^{71}\left(X_{J(k+2)}\right)+\sum_{j=68}^{71}\left(X_{J(k+3)}\right) \leq 1
$$

$\mathrm{k}=1,2,3, \ldots, 27$

Her pilavın üç günde bir çıkması kısıtı;

$\mathrm{k}=1,2,3, \ldots ., 28$

$$
\sum_{j=72}^{74}\left(X_{j k}\right)+\sum_{j=72}^{74}\left(X_{J(k+1)}\right)+\sum_{j=72}^{74}\left(X_{J(k+2)}\right) \leq 1
$$

Her böreğin üç günde bir çıkması kısıtı; 
$\mathrm{k}=1,2,3, \ldots, 28$

$$
\sum_{j=75}^{78}\left(X_{j k}\right)+\sum_{j=75}^{78}\left(X_{J(k+1)}\right)+\sum_{j=75}^{78}\left(X_{J(k+2)}\right) \leq 1
$$

Her zeytinyağlının üç günde bir çıkması kısıtı;

$\mathrm{k}=1,2,3, \ldots ., 28$

$$
\sum_{j=79}^{84}\left(X_{j k}\right)+\sum_{j=79}^{84}\left(X_{J(k+1)}\right)+\sum_{j=79}^{84}\left(X_{J(k+2)}\right) \leq 1
$$

Her makarnanın üç günde bir çıkması kısıtı;

$\mathrm{k}=1,2,3, \ldots, 28$

$$
\sum_{j=85}^{89}\left(X_{j k}\right)+\sum_{j=85}^{89}\left(X_{J(k+1)}\right)+\sum_{j=85}^{89}\left(X_{J(k+2)}\right) \leq 1
$$

Her şerbetli tatlının üç günde bir çıkması kısıtı;

$$
\sum_{j=90}^{93}\left(X_{j k}\right)+\sum_{j=90}^{93}\left(X_{J(k+1)}\right)+\sum_{j=90}^{93}\left(X_{J(k+2)}\right) \leq 1
$$

$\mathrm{k}=1,2,3, \ldots, 28$

Her sütlü tatlının üç günde bir çıkması kısıtı;

$\mathrm{k}=1,2,3, \ldots, 28$

$$
\sum_{j=94}^{104}\left(X_{j k}\right)+\sum_{j=94}^{104}\left(X_{J(k+1)}\right)+\sum_{j=94}^{104}\left(X_{J(k+2)}\right) \leq 1
$$

Her meyvenin üç günde bir çıkması kısıtı;

$$
\sum_{j=105}^{115}\left(X_{j k}\right)+\sum_{j=105}^{115}\left(X_{J(k+1)}\right)+\sum_{j=105}^{115}\left(X_{J(k+2)}\right) \leq 1
$$

$\mathrm{k}=1,2,3, \ldots, 28$

Her salatanın üç günde bir çıkması kısıtı;

$$
\sum_{j=116}^{118}\left(X_{j k}\right)+\sum_{j=116}^{118}\left(X_{J(k+1)}\right)+\sum_{j=116}^{118}\left(X_{J(k+2)}\right) \leq 1
$$

$\mathrm{k}=1,2,3, \ldots, 28$

Her diğerlerinin üç günde bir çıkması kısıtı;

$\mathrm{k}=1,2,3, \ldots, 28$

$$
\sum_{j=119}^{122}\left(X_{j k}\right)+\sum_{j=119}^{122}\left(X_{J(k+1)}\right)+\sum_{j=119}^{122}\left(X_{J(k+2)}\right) \leq 1
$$

Hastalıklar için oluşan menülerde yemek sayısının kısıtlanması nedeniyle her hastalık için gün kısıtları da değişiklik göstermektedir. 


\subsection{Amaç Fonksiyonunun Belirlenmesi}

Çalışmada amaç fonksiyonu, besin öğeleri için oluşturulan hedef kısıtlarından sapmaların minimize edilmesi için kurulmuştur. $\mathrm{Bu}$ amaç fonksiyonu modelde şu şekilde gösterilmiştir:

$$
\text { Min } Z=d 1^{-}+d 2^{-}+d 3^{-}+d 4^{-}+d 5^{-}+d 6^{-}+d 7^{-}+d 8^{-}+d 9^{-}+d 10^{-}+d 11^{-}+d 12^{-}
$$

\subsection{Modelin Çözümü}

Matematiksel modelde hedef kisitlardan sapmalar minimize edilerek, amaç fonksiyonu oluşturulmuştur. Modele genel kısıtlar eklenerek yemeklerin uyumsuz, gün kısitları eklenerek yemeklerin belirli süre ard arda çıkması engellenmiştir. Model ILOG 12.6.2 paket programında çözülmüştür. Program bir kere çalıştırıldığında bir aylık menü ortaya çıkmıştır. Hastane personelleri için oluşturulan modele ayrı ayrı diyabet, mide ve karaciğer hastaları için hastalık kısıtları da eklenerek yine bir aylık üç menü daha oluşturulmuştur. Tablo.7'de hastane personelleri için oluşturulan menü verilmiştir.

Tablo 7.Hastane Personelleri İçin Oluşturulan Menü Planı

\begin{tabular}{|c|c|c|c|c|}
\hline 1. GÜN & 2.GÜN & 3.GÜN & 4.GÜ N & 5.GÜN \\
\hline Mengen Ç orbas1 & Soğuk A yran Çorbası & Sebze Çorbası & Misrr Çorbası & Havuç Ç orbas1 \\
\hline Orman Kebab 1 & Frrmda Tavuk But & Somon Izgara & Kadmbudu Köfte & Mant1 \\
\hline Cevizli Eriște & Bulgur Pilavı & Patatesli Börek & Makarna & Zeytinyağh B arbunya \\
\hline Tiramisu & Baklava & Çoban Salata & Sütlaç & Muz \\
\hline 6.GÜN & 7.GÜN & 8.GÜN & 9.GÜN & 10.GÜN \\
\hline Bự̆day Unu Çorbası & Mengen Ç orbas 1 & Yoğurt Çorbası & Şehriye Çorbası & Ezogelin Çorbas1 \\
\hline Frrnda Tavuk But & Etli Kuru Fasulye & Mercimekli Köfte & Mant1 & Tavuk But Haşlama \\
\hline Su Böreği & Cevidi Eriște & Şehriyeli Pilav & Kuru F asulye Piyaz & Makama \\
\hline Vişne Kompostosu & Limonlu İmik Taths & Şekerpare & Kiraz & Limonlu İrmik Tathsı \\
\hline 11.GÜN & 12.GÜN & 13.GÜN & 14.GI்N & 15.GÏUN \\
\hline Taze Fasulye Ç orbası & Soğuk A yran Çorbası & Zerdaçalh Tavuk Çorba & Patates Çorbası & Tavuksuyu Çorbası \\
\hline Çitrr Balik (kizartma) & Rasto Köfte & Orman Kebab1 & Tavuk But Hașlama & Etti Kunu $\mathrm{F}$ asulye \\
\hline Patatesli Börek & Kuru Fasulye Piyazı & Erişte & Bulgur Pilavı & Milföy Böreği \\
\hline Çoban Salata & Portakal & Baklava & Aşure & Vișne K ompostosu \\
\hline $16 . \mathrm{G} \ddot{\mathrm{UN}}$ & 17.GÜN & 18.GüN & 19.GÜN & 20.GÜN \\
\hline Havuç Çorbas1 & Tarhana Ç orbası & Buğdday Unu Çorbası & Sebze Çorbas1 & Yeşil Mercimek Çorbası \\
\hline Mercimekli Köfte & Buğu Kebab1 & Tavuk Ş iş & Çıtrr Bahk (kızartma) & Etli Nohut \\
\hline Finnda Makarna & Zeytinyağh 1 Barbunya & Su Böreği(1 adet) & Erişte & Sade Pirinç Pilavı \\
\hline Şekerpare & Sütlaç & Portakal & Tel Kadayif & Așure \\
\hline 21.GÜN & 22.G:ÜN & 23.G $\ddot{\mathbf{U}} \mathbf{N}$ & 24.GÜN & 25.GÜN \\
\hline Zerdaçall Tavuk Corba & Ezogelin Ç orbas1 & Mercimek Corbas 1 & Tavuksuyu Corbası & Patates Corbas 1 \\
\hline Pathcan Kebabi & Frrmda Piliç Pirzola & Kadmbudu Köfte & Etli Nohut & Buğu Kebab1 \\
\hline Yeșil Mercimekli Börek & Frrmda Makarna & Şehriyeli Pilav & Yeșil Mercimekli Börek & Makama Salatas 1 \\
\hline Kiraz & Revani & Trileçe & Armut & Revani \\
\hline 26.GÜN & $27 . G \ddot{U} \mathbf{N}$ & 28.G $\ddot{\mathbf{U} N}$ & 29.G̈̈N & 30.GÜN \\
\hline Tarhana Çorbası & Mercimek Çorbası & Mısır Ç orbası & Yeșil Mercimek Çorbası & Șehriye Çorbası \\
\hline Furnda Piliç Pirzola & Somon Izgara & Rosto Köfte & Pathean Kelbab1 & Beșamel Soslu Tavuk \\
\hline Zeytinyağh Yaprak Sarma & Milföy Böreği & Makarna Salatas1 & Sade Pirinç Pilav & Zeytinyağl1 Yaprak Sarma \\
\hline Trileçe & Armut & Tel Kadaylf & Tiramisu & Mevsim Salata \\
\hline
\end{tabular}

Tablo.8'de mide hastalığı olanlar için oluşturulan menü verilmiştir. 
Tablo 8. Mide Hastalı̆̆ı Olan Kişiler İçin Menü Planı

\begin{tabular}{|c|c|c|c|c|}
\hline 1. GÜN & 2.GÜN & 3.GÜN & 4.GÜN & 5.GÜN \\
\hline Tavuksuyu Çorbası & Patates Çorbası & Mercimek Çorbası & Buğday Unu Çorbası & Mengen Çorbası \\
\hline Bahçevan Kebap & Kadmbudu Köfte & Frrmda Piliç Pirzola & Patlican Kebab1 & Somon Izgara \\
\hline Sade Pirinç Pilavı & Cevizli Eriște & Zeytinyağh Prrasa & Sade Pirinç Pilavı & Makarna \\
\hline Muz & Yoğurt & Sütlü İrmik Tatlısı & Kiraz & Vişne Kompostosu \\
\hline 6.GÜN & 7.GÜN & 8.GÜN & 9.GÜN & 10.GÜN \\
\hline Bezelye Çorbası & Tavuksuyu Çorbası & Mısır Çorbası & Havuç Çorbası & Yoğurt Çorbası \\
\hline İzmir Köfte & Et Sote & Frrmda Piliç Pirzola & Kadınbudu Köfte & Buğu Kebab1 \\
\hline Zeytinyağh Yaprak Sarma & Sade Pirinç Pilavı & Makarna & Zeytinyağh Prrasa & Şehriyeli Pilav \\
\hline Sütlü İrmik Tatlısı & Muz & Cacık & Sakızlı Muhallebi & Kiraz \\
\hline 11.GÜN & 12.GÜN & 13.GÜN & 14.GÜN & 15.GÜN \\
\hline Yeșil Mercimek Çorbası & Sebze Çorbası & Soğuk Ayran Çorbası & Șehriye Çorbası & Misır Çorbası \\
\hline Alabalık Buğulama & Rosto Köfte & Pathcan Kebab1 & Frrmda Tavuk But & $\begin{array}{l}\text { Rosto Köfte } \\
\end{array}$ \\
\hline Makarna & Zeytinyağhı Prrasa & Şehriyeli Pilav & Erişte & Zeytinyağlı Yaprak Sarma \\
\hline Vişne Kompostosu & Yoğurt & Armut & Ayran & \begin{tabular}{|c|} 
Ayran \\
\end{tabular} \\
\hline 16.GÜN & 17.GÜN & 18.GÜN & 19.GÜN & 20.GÜN \\
\hline Mengen Çorbası & Ezogelin Çorbası & Buğday Unu Çorbası & Soğuk Ayran Çorbası & Yeşil Mercimek Çorbası \\
\hline Hamsi Buğulama & Orman Kebabı & Rosto Köfte & Tavuk But Haşlama & Bahçevan Kebap \\
\hline Sade Pirinç Pilavı & Cevizli Erişte & \begin{tabular}{|l|} 
Zeytinyağı Yaprak Sarma \\
\end{tabular} & Sade Pirinç Pilavı & Cevizli Erişte \\
\hline Armut & Sakızh Muhallebi & \begin{tabular}{|c|} 
Vişne Kompostosu \\
\end{tabular} & Muz & Sütlü İrmik Tatlısı \\
\hline 21.GÜN & 22.GÜN & 23.GÜN & 24.GÜN & 25.GÜN \\
\hline Ezogelin Çorbası & Mercimek Çorbası & Taze Fasulye Çorbası & Havuç Çorbası & Sebze Çorbası \\
\hline İzmir Köfte & Alabalkk Buğulama & Orman Kebab1 & İzmir Köfte & Tavuk But Haşlama \\
\hline Zeytinyağh Taze Fasulye & Şehriyeli Pilav & Cevizli Eriște & Zeytinyağglı Prrasa & Șehriyeli Pilav \\
\hline Ayran & Armut & Sakızh Muhallebi & Cack & Cack \\
\hline 26.GÜN & 27.GÜN & 28.GÜN & 29.GÜN & 30.GÜN \\
\hline Patates Çorbası & Şehriye Çorbası & Bezelye Corbası & Taze Fasulye Corbası & Tutmaç Çorbası \\
\hline Buğu Kebabı & \begin{tabular}{|l|} 
Somon Izgara \\
\end{tabular} & Kadinbudu Köfte & Et Sote & \begin{tabular}{|c|} 
Tavuk Șiş \\
\end{tabular} \\
\hline Erişte & Zeytinyağlı Taze Fasulye & Şehriyeli Pilav & Makarna & \begin{tabular}{|l} 
Zeytinyağlı Yaprak Sarma \\
\end{tabular} \\
\hline Sütlü İrmik Tatlısı & Kiraz & Yoğurt & Sakılı Muhallebi & Kayıs1 \\
\hline
\end{tabular}

\section{Tablo.9'da karaciğer hastalığı olanlar için oluşturulan menü verilmiştir.}

\section{Tablo 9.Karaciğer Hastalığı Olan Kişiler İçin Yapılan Menü Planı}

\begin{tabular}{|c|}
\hline 1. GÜ N \\
\hline Sebze Çorbas1 \\
\hline Tavuk But Haşlama \\
\hline Sade Prinç Pilav1 \\
\hline Trileçe \\
\hline 6.GÜ N \\
\hline Şehriye Çorbas1 \\
\hline Frmda Tavuk But \\
\hline Patatesli Börek \\
\hline Ayran \\
\hline 11.GÜ N \\
\hline Tarhana Çorbas1 \\
\hline Mant1 \\
\hline Zeytinyağlı Karnabahar \\
\hline Portaka1 \\
\hline 16.GÜ N \\
\hline Bezelye Çorbas1 \\
\hline Izmir Köfte \\
\hline Şehriyeli Pilav \\
\hline Sakıł Muhallebi \\
\hline 21.GÜ N \\
\hline Şehriye Çorbası \\
\hline Somon Izgara \\
\hline Makarna \\
\hline Vişne Kompostosu \\
\hline 26.GÜ N \\
\hline Ispanak Çorbas1 \\
\hline Patlıcan Kebab1 \\
\hline Sade Prinç Pilav1 \\
\hline Elma \\
\hline
\end{tabular}

\begin{tabular}{|c|}
\hline 2.GÜN \\
\hline Balkabağ 1 Çorbas1 \\
\hline Orman Kebab1 \\
\hline Cevizh Eriște \\
\hline Armut \\
\hline 7.GÜN \\
\hline Domates Çorbas 1 \\
\hline Rosto Köfte \\
\hline Șehriyeli Pilav \\
\hline Limonhu Irmik Tathsi \\
\hline 12.GÜN \\
\hline Un Çorbası \\
\hline Tavuk But Hașlama \\
\hline Cevizli Eriște \\
\hline Vişne Kompostosu \\
\hline 17.GÜN \\
\hline Tutmaç Çorbası \\
\hline Bahçevan Kebap \\
\hline Zeytinya gld $_{1}$ Karnabahar \\
\hline Kiraz \\
\hline 22.GÜN \\
\hline Bezelye Çorbas 1 \\
\hline Rosto Köfte \\
\hline Sade Pirinç Pilavi \\
\hline Sakızlı Muhallebi \\
\hline $27 . \mathrm{GÜN}$ \\
\hline Misir Çorbası \\
\hline Somon Izgara \\
\hline Patatesli Börek \\
\hline Çoban Salata \\
\hline
\end{tabular}

\begin{tabular}{|c|}
\hline 3.GUN \\
\hline Domates Çorbas 1 \\
\hline A labalık Bữulama \\
\hline Su Böre öj \\
\hline Mevsim Salata \\
\hline 8.GUN \\
\hline Un Çorbas1 \\
\hline Bahçevan Kebap \\
\hline Cevizhi Eriște \\
\hline Kiraz \\
\hline 13.GÜN \\
\hline Taze Fasulye Çorbası \\
\hline Izmir Köfte \\
\hline Sade Pirinç Pilavı \\
\hline Sütlü Irmik Tatlss \\
\hline 18.GÜ N \\
\hline Ispanak Corbas 1 \\
\hline Frrmda Piliç Pirzola \\
\hline Makarna \\
\hline Vişne Kompostosu \\
\hline 23.GÜN \\
\hline Taze Fasulye Çorbas \\
\hline Mantı \\
\hline Zeytinyağh Prasa \\
\hline Muz \\
\hline 28.GÜN \\
\hline Tarhana Corbas 1 \\
\hline Rosto Köfte \\
\hline Erişte \\
\hline Sütlü frmik Ta \\
\hline
\end{tabular}

\begin{tabular}{|c|}
\hline 4.GUN \\
\hline Patates Corbas1 \\
\hline Kadmbudu Köfte \\
\hline Sade Prinç Pilav1 \\
\hline Trileçe \\
\hline 9.GUN \\
\hline Ezogelin Çorbasi \\
\hline Alabalik Buğulama \\
\hline Milfóy Böreği \\
\hline Çoban Salata \\
\hline 14.GÜN \\
\hline Mantar Corbas 1 \\
\hline Buğu Kebab1 \\
\hline Zeytinyağlı Prasa \\
\hline Portakal \\
\hline 19.GÜN \\
\hline Msir Çorbas1 \\
\hline Kadmbudu Köffe \\
\hline Şehriyeli Pilav \\
\hline Sütlaç \\
\hline 24.GÜN \\
\hline Ezogelin Çorbası \\
\hline Frrmda Piliç Pirzola \\
\hline Su Böreği \\
\hline Akdeniz Salata \\
\hline 29.GÜN \\
\hline Tutmaç Çorbası \\
\hline Buğu Kebab1 \\
\hline Şehriye bi Pilav \\
\hline Armut \\
\hline
\end{tabular}

\begin{tabular}{|c|}
\hline 5.GUN \\
\hline Mantar Çorbas1 \\
\hline Patlican Kebab1 \\
\hline Erişte \\
\hline Muz \\
\hline 10.GUN \\
\hline Sebze Çorbas1 \\
\hline fzmir Köfte \\
\hline Șehriyeli Pilav \\
\hline Limonlu Irmik Tatls 1 \\
\hline 15.GÜN \\
\hline Patates Çorbas 1 \\
\hline Hamsi Buğulama \\
\hline Makarna \\
\hline Mevsim Salata \\
\hline 20.GÜN \\
\hline Balkabağ Ç orbasi \\
\hline Orman Kebab1 \\
\hline Zeytinyağglı K arnabahar \\
\hline Elma \\
\hline 25.GÜN \\
\hline Havuç Çorbası \\
\hline Kadmbudu Köfte \\
\hline Erişte \\
\hline Sütlaç \\
\hline 30.GÜN \\
\hline Havuç Çorbası \\
\hline Tavuk Goğgis Haşlama \\
\hline Milfóy Böreği \\
\hline Akdeniz Salata \\
\hline
\end{tabular}


Tablo.10'da diyabet hastalığg olanlar için oluşturulan menü verilmiştir.

\section{Tablo 10. Diyabet Hastalı̆̆ Olan Kişiler Iç̧in Menü Planı}

\begin{tabular}{|c|c|c|c|c|}
\hline 1. GÜN & 2.GÜN & 3.GÜN & 4.GÜN & 5.GÜN \\
\hline Sebze Çorbası & Tavuksuyu Çorbası & Soğuk Ayran Çorbası & Yeșil Mercimek Çorbas1 & Misır Çorbası \\
\hline Frrmda Piliç Pirzola & Orman Kebab1 & Mercimekli Köfte & Hamsi Buğulama & Furmda Piliç Pirzola \\
\hline Zeytinyağh Barbunya & Bulgur Pilav & Zeytinyağhlı Barbunya & Milfóy Böreği & Bulgur Pilavı \\
\hline Akdeniz Salata & Kiraz & Mevsim Salata & Kiraz & Yogurt \\
\hline 6.GÜN & 7.GÜN & 8.GÜN & 9.GÜN & 10.GÜN \\
\hline Havuç C Corbası & Tutmaç C orbası & Tavuksuyu C orbası & Yoğurt Corbası & Ș ehriye Corbas 1 \\
\hline Buğu Kebab1 & Rosto Köfte & Etli Nohut & Buğu Kebab1 & Tavuk But Haşlama \\
\hline Zeytinyağhl Barbunya & Bulgur Pilavı & Milfóy Böreği & Zeytinyağlı Barbunya & Bulgur Pilav \\
\hline Akdeniz Salata & Armut & Çoban Salata & Portakal & Cacik \\
\hline 11.GŨN & 12.GUN & 13.GUN & 14.GUN & 15.GÜN \\
\hline Mercimek Çorbası & Tavuk Çorbası & Ezogelin Çorbası & Şehriye Çorbası & Sebze Çorbas 1 \\
\hline Alabalik Buğulama & Orman Kebab1 & Kadmbudu Köfte & Köri Soshu Tavuk & Buğu Kebab1 \\
\hline Milfóy Böreği & Bulgur Pilavı & Kuru Fasulye Piyaz & Bulgur Pilavi & Milfóy Böreği \\
\hline Croban Salata & Elma & Akdeniz Salata & Armut & Ayran \\
\hline 16.GÜN & 17.GÜN & 18.GÜN & 19.GÜN & 20.GÜN \\
\hline Tavuk Çorbası & Soğuk Ayran Çorbası & Yoğurt Çorbası & Tutmaç Çorbası & Mercimek Corbası \\
\hline Etli Nohut & Kadınbudu Koffe & Tavuk But Haşlama & Orman Kebab1 & Somon Izgara \\
\hline Bulgur Pilavi & Kuru Fasulye Piyaz & Milfóy Böreği & Zeytinyağh Karnabahar & Bulgur Pilavı \\
\hline Elma & Mevsim Salata & Armut & Mevsim Salata & Portakal \\
\hline 21.GÜN & 22.GÜN & 23.GÜN & 24.GÜN & 25.GÜN \\
\hline Havuç Corbası & Buğday Unu Ç orbası & Zerdaçath Tavuk Çorba & Ezogelin Corbas1 & Yeşil Mercimek Corbası \\
\hline Rosto Köfte & Frrmda Piliç Pirzola & Etli Nohut & Pathe an Kebab1 & Citur Bahk (kızartma) \\
\hline Kuru F asulye Piyaz & Milföy Böreği & Bulgur Pilavı & Kuru Fasulye Piyaz & Bulgur Pilavı \\
\hline Ayran & Portakal & Mevsim Salata & Ayran & Elma \\
\hline 26.GÜN & 27.GÜN & 28.GÜN & 29.GÜN & 30.GÜN \\
\hline Tarhana Çorbas1 & Misrr Çorbas1 & Buğday Unu Ç orbası & Zerdaçalh Tavuk Çorba & Tarhana Çorbas1 \\
\hline Tavuk But Hașlama & Etli Kuru F asulye & Mercimekli Kofte & Pathcan Kebab1 & Beșamel Soslu Tavuk \\
\hline Kuru Fasulye Piyaz & Milfóy Böreği & Zeytinyağh Kamabahar & Milfóy B Böreğgi & Zeytinyağhl Barbunya \\
\hline Akdeniz Salata & Ayran & Coban Salata & Kiraz & Coban Salata \\
\hline
\end{tabular}

Tablo 11. Hedeflenen Besin Değerlerinden Sapma Miktarları

\begin{tabular}{|c|c|c|c|c|c|c|c|c|c|c|c|c|c|}
\hline & & $\frac{\check{\tilde{\sigma}}}{\tilde{J}}$ & 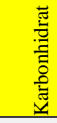 & 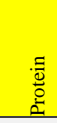 & & 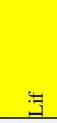 & $\begin{array}{l}\overline{0} \\
\overline{0} \\
\frac{0}{0} \\
\stackrel{0}{0}\end{array}$ & 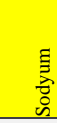 & 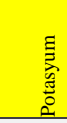 & 离 & $\begin{array}{l}\varangle \\
\text { 吉 } \\
\stackrel{\Xi}{=}\end{array}$ & 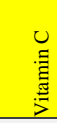 & 节 \\
\hline \multirow{3}{*}{ NORMAL } & HEDEFLER & $\begin{array}{l}735, \\
0\end{array}$ & 94,5 & 42,0 & 26,3 & 26,3 & $\begin{array}{l}126, \\
0\end{array}$ & $\begin{array}{l}840, \\
0\end{array}$ & $\begin{array}{l}1575, \\
0\end{array}$ & $\begin{array}{l}525, \\
0\end{array}$ & $\begin{array}{l}945, \\
0\end{array}$ & 52,5 & 9,5 \\
\hline & ORTALAMA & $\begin{array}{l}602, \\
0\end{array}$ & 67,6 & 28,5 & 23,3 & 7,3 & 80,6 & $\begin{array}{l}585, \\
7\end{array}$ & 903,7 & $\begin{array}{l}179, \\
1\end{array}$ & $\begin{array}{l}164, \\
8\end{array}$ & 44,5 & 4,0 \\
\hline & SAPMA(\%) & 18,1 & 28,5 & 32,2 & 11,3 & 72,3 & 36,1 & 30,3 & 57,4 & 65,9 & 82,6 & 15,3 & 57,8 \\
\hline \multirow{3}{*}{ DIYABET } & HEDEFLER & $\begin{array}{l}735, \\
0\end{array}$ & 94,5 & 42,0 & 26,3 & 26,3 & $\begin{array}{l}126, \\
0\end{array}$ & $\begin{array}{l}840, \\
0 \\
\end{array}$ & $\begin{array}{l}1575, \\
0\end{array}$ & $\begin{array}{l}525, \\
0 \\
\end{array}$ & $\begin{array}{l}945, \\
0\end{array}$ & 52,5 & 9,5 \\
\hline & ORTALAMA & $\begin{array}{l}515, \\
4\end{array}$ & 68,1 & 29,4 & 24,2 & 10,0 & 77,4 & $\begin{array}{l}609, \\
2\end{array}$ & $\begin{array}{l}1099, \\
4\end{array}$ & $\begin{array}{l}198 \\
1\end{array}$ & $\begin{array}{l}309, \\
3\end{array}$ & 86,4 & 5,3 \\
\hline & SAPMA(\%) & 29,9 & 28,0 & 30,1 & 7,9 & 62,1 & 38,6 & 27,5 & 69,8 & 62,3 & 67,3 & 64,5 & 44,3 \\
\hline \multirow{3}{*}{ MIDE } & HEDEFLER & $\begin{array}{l}735, \\
0\end{array}$ & 94,5 & 42,0 & 26,3 & 26,3 & $\begin{array}{l}126, \\
0\end{array}$ & $\begin{array}{l}840, \\
0\end{array}$ & $\begin{array}{l}1575, \\
0\end{array}$ & $\begin{array}{l}525, \\
0\end{array}$ & $\begin{array}{l}945, \\
0\end{array}$ & 52,5 & 9,5 \\
\hline & ORTALAMA & $\begin{array}{l}481, \\
5\end{array}$ & 50,2 & 23,8 & 20,2 & 4,8 & 59,2 & $\begin{array}{l}457, \\
5\end{array}$ & 739,7 & $\begin{array}{l}138, \\
4\end{array}$ & $\begin{array}{l}170 \\
2\end{array}$ & 32,2 & 3,1 \\
\hline & SAPMA(\%) & 34,5 & 46,9 & 43,3 & 23,0 & 81,6 & 53,0 & 45,5 & 47,0 & 73,6 & 82,0 & 38,7 & 67,0 \\
\hline KARACİĞER & HEDEFLER & $\begin{array}{l}735, \\
0\end{array}$ & 94,5 & 42,0 & 26,3 & 26,3 & $\begin{array}{l}126, \\
0\end{array}$ & $\begin{array}{l}840, \\
0\end{array}$ & $\begin{array}{l}1575, \\
0\end{array}$ & $\begin{array}{l}525, \\
0\end{array}$ & $\begin{array}{l}945, \\
0\end{array}$ & 52,5 & 9,5 \\
\hline
\end{tabular}




\begin{tabular}{|l|l|l|l|l|l|l|l|l|l|l|l|l|l|} 
& ORTALAMA & $\begin{array}{l}493, \\
7\end{array}$ & 52,8 & 23,8 & 20,8 & 5,2 & 67,9 & $\begin{array}{l}567, \\
6\end{array}$ & 773,5 & $\begin{array}{l}155, \\
2\end{array}$ & $\begin{array}{l}175, \\
6\end{array}$ & 48,9 & 3,2 \\
\hline & SAPMA(\%) & 32,8 & 44,2 & 43,4 & 20,7 & 80,2 & 46,2 & 32,4 & 49,1 & 70,4 & 81,4 & 6,9 & 66,1 \\
\hline
\end{tabular}

Tablo 11'de hastane personeli ve hastalıklar için oluşturulan menülerin hedef değerlerden sapma miktarları gösterilmektedir. Çıkan sapmaların arasındaki farklar çalışmada, hastalıklar için hem yasaklı yemeklerin olması hem de kullanılan yemek listesinin kısıtlı olmasından kaynaklanmaktadır. Ayrıca hedef değerlerin varsayım değerler olarak alınması sapma miktarlarına etki etmektedir. $\mathrm{Bu}$ farklılıklar yemek listesinin zenginleştirilmesi ile daha da uygun hale gelecektir.

\section{SONUÇ}

$\mathrm{Bu}$ çalışmada hastaların beslenme durumları dikkate alınmış ve Bulanık Hedef Programlama tekniği kullanılarak, menü planlaması için matematiksel model oluşturulmuştur. Hastaların bir günde öğle yemeğinde alması gereken kalori, karbonhidrat, protein, yă kolesterol, sodyum, potasyum, kalsiyum, A Vitamini, C Vitamini ve demir değerlerine dikkat edilmiştir. Elde edilen bu bilgiler ve uygulamada ulaşılması istenen sonuçlar uzman kişilerle ortaya konmuştur. Alınması gereken hedef değerler \%5 bulanıklaştırılmış, hedef değerin $\% 5$ fazlası ve eksiği şeklinde değer kümesi genişletilmiştir. Matematiksel model ILOG paket programı kullanılarak çözülmüştür. Model çözüldügüüde hastane personelleri için 30 günlük bir menü çıkarılmıştır. Kurulan matematiksel model diyabet, mide ve karaciğer hastalıkları için özelleştirilerek toplamda dört adet otuz günlük menü planı yapılmıştır.

Literatürde çeşitli yollarla menü planı yapılabilmesine rağmen diyabet, mide ve karaciğer hastası kişiler için yapılabilen bir menü planlaması programıyla karşılaşılmamıştır. Çünkü hastalıklar için oluşturulan modellerde özel birçok kısıt vardır. Her hasta için beslenme, hastalığın da farklı türleri göz önüne alınırsa çok farklı şekillerde olabilmektedir. Yapılan çalışmada bu hastalık kısıtları uzman kişi ile belirlenmiş ve çok özel durumlar dikkate alınmayarak varsayımlar ortaya konmuştur. Daha sonra sonuçlar değerlendirilmiş ve doğruluğu kabul edilmiştir. Uygulama 
yapılacak yerlerde mevcut hastaların beslenmelerine göre gerekirse modelde değişiklikler yapılarak hemen hemen her yerde uygulanabilmektedir. Böylece hastanelerde bir aylık bir menünün oluşturulması için gereken zamandan tasarruf sağlanmıştır. Aynı zamanda sistematik bir yapı ortaya çıkarılmıştır. Çalışmanın uygulanmasıyla ortaya çıkan sistematik yap1 sayesinde hastanelerdeki satın alma konuları da düzenli bir yapıda ilerleyebilmektedir.

\section{KAYNAKÇA}

Açık, M., “Türk Silahlı Kuvvetleri'nde Birliklerin Yeniden Yapılandırılmasında Hedef Programlama Yönteminin Uygulanması", İstanbul Teknik Üniversitesi, Fen Bilimleri Enstitüsü, Yüksek Lisans Tezi, 2002.

Akay, A., Sarışı, M., "Restoran Yöneticilerinin Menü Planlaması ve Analizi Konusuna Yaklaşımları Üzerine Bir Araştırma", Bartın Üniversitesi İktisadi ve İdari Bilimler Fakültesi Dergisi, 6(12), 211-230, 2015.

Akdeniz, A., Aras, S., “İzmir’de Kurulu Bir Plastik İşletmesinde Karar Vericinin Optimal Hedeflere Odaklanmasında Toplamsal Model Tabanlı Bulanık Hedef Programlama", Dokuz Eylül Üniversitesi Sosyal Bilimler Enstitüsü Dergisi, 12(3), 07-19,2010.

Aksarayl1, M., Pala, Osman., Aksoy, M.A., Turaba, L., “A Fuzzy Mixed Integer Goal Programming Approach for Academic Performance Modeling" Akademik Sosyal Araştırmalar Dergisi, 4(34), 14-32, 2016.

Atılan, M., “Adana'da Toplu Beslenme Yapılan Bazı Kurumların Menülerinin Değerlendirilmesi ve Tüketici Görüşlerinin Belirlenmesi”, Çukurova Üniversitesi, Fen Bilimleri Üniversitesi, Gıda Mühendisliği Anabilim Dalı, Yüksek Lisans Tezi, Adana, 2008.

Aydemir Karadağ, A., Türkbey, O., "Demontaj Hattı Dengeleme Problem: Hedef Programlama Ve Bulanık Hedef Programlama Modelleri” 2011. 
Baykasoğlu, A., Taşkıran, D., Akkoyun, H. G., "Toplu Beslenme İçin Menü Planlama Karar Destek Sistemi Geliştirilmesi ve Uygulanması", Gazi Üniversitesi Mühendislik ve Mimarlık Fakültesi Dergisi, 31(1), 191-200,2016.

Benvenuti, L., De Santis, A., Santesarti, F., Tocca, L., “An Optimal Plan For Food Consumption With Minimal Environmental Impact: The Case Of School Lunch Menus" Journal of Cleaner Production, 129, 704-713, 2016.

Beyhan, Y., ve Ciğerim, N. "Toplu Beslenme Sistemlerinde Menü Yönetimi ve Denetimi”, Ankara: Kök Yayıncılık, (1995).

Bilge, E., "Bir İşletmede Çalışanların Beslenme Durumları ve Enerji Harcamalarının Değerlendirilmesi”, Trakya Üniversitesi, Sağlık Bilimleri Enstitüsü, Halk Sağlı̆ Anabilim Dalı, Yüksek Lisans Tezi, Edirne,2009.

Çalışkan, F., Sungur, B., "Vasıflı Kayan Esnek Çalışma Saati Sistemi İçin Bir Karma Tam Sayılı Hedef Programlama Modeli Önerisi”, Erciyes Üniversitesi İktisadi ve İdari Bilimler Fakültesi Dergisi, 33, 01-18,2009.

Dağdeviren, M., Akay, D., Kurt, M., "İş Değerlendirme, Faktör Derece Puanlarının Belirlenmesinde Hedef Programlama Yönteminin Kullanılması", Gazi Üniversitesi Mühendislik ve Mimarlık Fakültesi Dergisi, 19(1), 89-95,2004.

Dağdeviren, M., Eren, T., "Tedarikçi Firma Seçiminde Analitik Hiyerarşi Prosesi ve 0-1 Hedef Programlama Yöntemlerinin Kullanılması", Gazi Üniversitesi Mühendislik ve Mimarlık Fakültesi Dergisi,16(2), 41-52,2001.

Ediz, A., Yağdıran, Y., "Hedef Programlama Tekniği ile Menü Planlaması", Gazi Üniversitesi İktisadi ve İdari Bilimler Fakültesi Dergisi, 11(1), 45-74, 2009.

Ekinci, N., "Otel İşletmelerinde Menü Planlaması, Menü Fiyatlandırma Yöntemleri ve İstanbul Sürmeli Otel Uygulaması", Gazi Üniversitesi, Sosyal Bilimler Enstitüsü, İşletme Anabilim Dalı, Yüksek Lisans Tezi, Ankara, 2010. 
Erdin, C., "Bulanık Hedef Programlama ve Su Havzasında Bir Uygulama", Yıldız Teknik Üniversitesi, Yüksek Lisans Tezi, İstanbul, 2008.

Erdoğmuş, Ş., Koç, E., Öğütlü, A.S., "Diyet Probleminin Çözümünde Kullanılabilecek Bazı Eniyileme Tekniklerinin Yaklaşım Farklılıklarının Değerlendirilmesi”, Afyon Kocatepe Üniversitesi, Fen Bilimleri Dergisi, 5(1), 7790,2015 .

Erpolat, S., "Üretim Planlamasında Hedef Programlama ve Bulanık Hedef Programlama Yöntemlerinin Karşılaştırılması" Mimar Sinan Güzel Sanatlar Üniversitesi, Fen Edebiyat Fakültesi Öneri, 9(34), 2010.

Ersin Bayrak, Mehtap., "Diyabette "Tibbi Beslenme Tedavisi", Ekonomik Forum Dergisi, 34-35, 2014.

Ertuğrul, İ., Öztaş, G.Z., "Ders Programı Oluşturulmasında 0-1 Tam Sayılı Bulanık Hedef Programlama Yaklaşımı", Niğde Üniversitesi İktisadi ve İdari Bilimler Fakültesi Dergisi, 9(1), 159-177, 2016.

Frampton, A. M., Sisson, S. B., Horm, D., Campbell, J. E., Lora, K., Ladner, J. L., "What's for lunch? An analysis of lunch menus in 83 urban and rural Oklahoma child-care centers providing all-day care to preschool children", Journal of the Academy of Nutrition and Dietetics, 114(9), 1367-1374, 2014.

Girginer, N., Kaygısız, Z., “İstatistiksel Yazılım Seçiminde Analitik Hiyerarşi Süreci ve 0-1 Hedef Programlama Yöntemlerinin Birlikte Kullanımı", Eskişehir Osmangazi Üniversitesi Sosyal Bilimler Dergisi, 10(1), 2009.

Güçlü, P., Özdemir, A., "Bulanık Hedef Programlama İle Tedarik Zinciri Optimizasyonu: Tekstil Sektöründe Bir Uygulama”, Hacettepe Üniversitesi İktisadi ve İdari Bilimler Fakültesi Dergisi, 33(1), 79-100, 2015.

Gülenç, İ.F., Karabulut, B., "Doğrusal Hedef Programlama ile Bir Üretim Planlama Probleminin Çözümü”, Kocaeli 
Üniversitesi Sosyal Bilimler Enstitüsü Dergisi, 9(1), 5568,2005 .

Güngör, M., Umarusman, N., Güneş, M., "Sermaye Kısıtları Altında Hedef Programlama Ve Bulanık Hedef Programlamanın En İyi Fiyat Belirleme Süreçlerinde Kullanılması Ve Bir Uygulama” 2011.

IBM ILOG CPLEX v12.6.2: User's manual for Cplex, available from www.ibm.com; 2009.

Kağnıcıoğlu, C.H., Yıldız, A., "0-1 Tam Sayılı Bulanık Hedef Programlama Yaklaşımı İle Sınav Görevi Atama Probleminin Çözümü’, Anadolu Üniversitesi Bilim Ve Teknoloji Dergisi, 7(2), 413-429, 2006.

Karaman, E., Kale, S., "Bulanık Hedef Programlama Yöntemi ile Süre-Maliyet-Kalite Eniyilemesi”, Yapı Dünya Dergisi, 4955, 2007.

Koşan, L., "Menü Analizinde Geleneksel ve Çağdaş Yöntemlerin Karşılaştırılması", Niğde Üniversitesi İktisadi ve İdari Bilimler Fakültesi Dergisi, 6(1), 203-219, 2013.

Körpeli, S., Şahin, B., Eren, T., "Hedef Programlama ile Menü Planlaması: Bir Örnek Uygulama”, Kırıkkale Üniversitesi Sosyal Bilimler Dergisi, 2(1), 121-142, 2012.

Leung, Stephen CH., Yue Wu And K. K. Lai, "Multi-Site Aggregate Production Planning With Multiple Objectives: A Goal Programming Approach Production Planning \& Control", 14(5), 425-436, 2003.

Medikal Akademi. (2016). 12 Eylül 2016 tarihinde https://www.medikalakademi.com.tr/karaciger-yaglanmasive-beslenme-koruyucu-ve-zararli-besinler/_adresinden erişildi.

Milliyet. 19 Eylül 2016 tarihinde http://www.milliyet.com.tr/midesorunu-olanlar-nasil-pembenar-detay-genelsaglik-2241909/ adresinden erişildi.

Narasimhan, R., Goal programming in a fuzzy environment, Decision Sciences, 11(2), 325-336, (1980). 
Orhan, İ., Kapanoğlu, M., Karakoç, T.H., "Hedef Programlama ile Bütünleşik Uçak Rotalama ve Bakım Çizelgeleme”, Gazi Üniversitesi Mühendislik ve Mimarlık Fakültesi Dergisi, 27(1), 11-26, 2012.

Oruç, K., O., "Bulanık Hedef Programlama ile Menü Planlama", Yönetim ve Ekonomi Araştırmaları Dergisi, 23, 2014.

Öztürk, Z.A., "Tesis Yeri Seçimi İçin Coğrafi Bilgi Sistemi Destekli Çok Amaçlı Bulanık Hedef Programlama Modeli”, Kara Harp Okulu Savunma Bilimleri Enstitüsü, Harekât Araştırması Ana Bilim Dalı, Yüksek Lisans Tezi, Ankara, 2015.

Pang, J., Hammond, D., "Efficacy And Consumer Preferences For Different Approaches To Calorie Labeling On Menus" Journal Of Nutrition Education And Behavior, 45(6), 669$675,2013$.

Sarıkaya, H.A., Çalıkan, E., Türkbey, O., "Bütünleşik Tedarik Zinciri Ağında Tesis Yeri Seçimi İçin Bulanık Çok Amaçlı Programlama Modeli” Pamukkale Üniversitesi Mühendislik Bilimleri Dergisi, 20(5), 150-161, 2014.

Sarucan, A., Atak, M., Yılmaz, Mustafa., "Enerji Talebinin Bulanık Olduğu Durumda Birincil Enerji Kaynaklarının Planlanması" Dünya Enerji Konseyi Türk Milli Komitesi Türkiye 10. Enerji Kongresi.

Seljak, B. K., "Computer-Based Dietary Menu Planning” Journal Of Food Composition And Analysis, 22(5), 414-420, 2009.

Soria-Contreras, D. C., Bell, R. C., McCargar, L. J., \& Chan, C. B., "Feasibility And Efficacy Of Menu Planning Combined With Individual Counselling To Improve Health Outcomes And Dietary Adherence In People With Type 2 Diabetes: A Pilot Study", Canadian Journal of Diabetes, 38(5), 320-325, 2014.

Şenol, S., "Menü Planlama Sorununa Karma Tam sayılı Programlama Modeli ile Çözüm Önerisi", Süleyman Demirel Üniversitesi, Sosyal Bilimler Enstitüsü, Ekonometri Anabilim Dalı, Yüksek Lisans Tezi, Isparta, 2011. 
Ünal, F.M., Eren, T., "Hedef Programlama İle Nöbet Çizelgeleme Probleminin Çözümü” Akademik Platform Mühendislik ve Fen Bilimleri Dergisi, 4, 1, 28-37, 2016.

Vatansever, R., "Proje Planlanmasında Bulanık Hedef Programlama Yaklaşımı" Yüksek Lisans Tezi, İstanbul Teknik Üniversitesi, İstanbul, 2008.

Zimmermann, H.J., "Fuzzy Programming And Linear Programming With Several Objective Functions", Fuzzy Sets and Systems, 1(1), 45-55, (1978). 